\title{
Institutional Investment and Commonality in Liquidity: Evidence from Transaction Data
}

\author{
Mahmoud Aymo* \\ Javier Gil-Bazo**
}

This version: December 20, 2013

\begin{abstract}
We study whether institutional investors' trading activity causes the liquidity of broad groups of stocks to move together, consistently with demand-side explanations of commonality in stock liquidity. In contrast to the previous literature, which uses stocks' institutional ownership as a proxy for institutional investors' trading activity, we use data on actual institutional investors' trades. We find that stocks that are highly traded by institutional investors exhibit strong commonality in liquidity. This result appears to be the consequence of correlated trading, as pairs of stocks connected through common institutional trading covary more together. Finally, we exploit the mutual fund scandal of 2003 to investigate the causal link between institutional trading activity and commonality in liquidity and find evidence suggesting that institutional investors' trades cause stock liquidity co-variation.
\end{abstract}

\footnotetext{
* Corresponding author. Department of Business Administration, Universidad Carlos III de Madrid, c/Madrid 126, 28903 Getafe, Spain. Email: maymo@emp.uc3m.es

** Department of Economics and Business, Universitat Pompeu Fabra, and Barcelona GSE, c/Ramon Trias Fargas 25-27, 08005 Barcelona, Spain. Email: javier.gil-bazo@upf.edu
} 


\section{Introduction}

In 1965, institutional investors held $16.2 \%$ of U.S. equities, this percentage has increased to $50.2 \%$ in 2010 according to the Board of Governors of the Federal Reserve System (2011). The fact that institutional investors are managing such a sizable share of the U.S. equity market has potential important consequences for price formation and liquidity. In this paper, we use institutional investors' transaction data to investigate whether institutional investors' trading activities can explain observed market-wide liquidity shocks.

Asset liquidity, that is, the ability to trade large quantities rapidly, at a low cost, and with little price impact, is of paramount importance to market participants. A number of studies document empirical evidence suggesting that investors require a compensation to invest in less liquid assets (see, e.g., Amihud and Mendelson, 1986; Amihud, 2002). But investors also care about how an asset's liquidity moves together with the liquidity of other stocks, i.e., commonality in liquidity. To the extent that liquidity risk cannot be fully diversified, investors require a risk premium for investing in a stock whose liquidity decreases precisely when liquidity is most needed, that is, in periods of liquidity dry-ups (Acharya and Pedersen, 2005; Pastor and Stambaugh, 2003; Korajczyk and Sadka, 2008). The recent financial crisis has evidenced the potential effects of market-wide liquidity dry-ups on the ability of financial intermediaries to provide liquidity to the real sector (Cornett et al., 2011). Although time-variation in market liquidity is well documented in the literature (Chordia et al., 2000; Hasbrouck and Seppi, 2001), the mechanism through which commonality in liquidity arises in stock markets is still not fully understood. Understanding how commonality in liquidity arises in financial markets could help investors better manage liquidity risk. Moreover, it would help market designers and regulators set rules that minimize the probability of liquidity dry-ups.

Two main sources of commonality in liquidity have been investigated in the literature. Coughenour and Saad (2004), Hameed et al. (2010), Comerton-Forde et al. (2010) and Brunnermeier and Pedersen (2009) posit that market-wide liquidity fluctuations are the consequence of the existence of market participants who provide liquidity to many assets. For instance, access to capital by market makers, hedge funds, and investment banks, may vary through time. Such variations affect their ability to provide liquidity and, to the extent 
that financial intermediaries operate in many assets simultaneously, they could cause liquidity comovement. As opposed to the supply-side explanation, other authors have argued in favor of a demand-side explanation. Institutional investors trade as a response to liquidity shocks or to the arrival of new information. For instance, when open-end mutual funds experience net outflows of money, they are often forced to liquidate their positions in order to meet redemptions. To the extent that these motives for trading affect a large number of institutional investors at the same time, there will be an increase in the demand for liquidity for the assets traded by institutions, which will in turn affect the liquidity of the traded assets (Chordia et al., 2000). Correlated trading across assets will be strengthened if different institutions concentrate their trades on the same assets due, for instance, to these institutions sharing similar investment styles. Karolyi et al. (2012) exploit the heterogeneity in market characteristics across stock exchanges to disentangle the plausibility of these competing views on the origin of commonality in liquidity and conclude that the empirical evidence is more consistent with the demand-side explanation: While commonality in liquidity is greater in countries with more correlated trading activity, as proxied by stock turnover, it does not increase in times when financial intermediaries are more likely to hit their capital constraints.

The purpose of our study is to reexamine the existing empirical evidence on the relationship between institutional investors' correlated trading and commonality in liquidity using data on actual institutional investors' trades. Previous attempts to establish a link between institutional investors' correlated trading activity and commonality in liquidity have suffered from lack of publicly available institutional trading data and have relied on various proxies for institutional trading activity. Kamara et al. (2008) use institutional ownership and index inclusion to proxy for institutional trading. Karolyi et al. (2012) use stock turnover to proxy for institutional trades. Koch et al. (2011) use a stock's mutual fund ownership, defined as the percentage of a firm's shares outstanding held by mutual funds, as well as quarterly changes in mutual fund ownership, to proxy for the amount of institutional investors' trading in the stock. The proxies used in the previous literature suffer from a number of limitations. Turnover does not distinguish between trading by institutions and trading by retail investors. While index inclusion (or exclusion) could be a good proxy for institutional trading, changes in the composition of an 
index are sparse and do not measure appropriately the volume of institutional investor trading activity or the correlation in trading across institutions. Institutional ownership overcomes both limitations, but it is also an imperfect proxy for institutional trading, as two firms with similar fractions of their shares held by institutional investors could experience very different trading activity if the institutions that invest in those companies differ in the frequency and size of their trades. Moreover, mutual fund ownership is likely to be associated with stock characteristics reflecting the portfolio choices of institutional investors, which may bias the results of the analysis if those characteristics are correlated with the outcome variable. Finally, changes in mutual funds' holdings is the proxy that comes closest to actual institutional trading activity. However, changes in institutional investors' holdings do not capture round trip trades between two consecutive portfolio disclosure dates. This problem becomes more severe if holdings are reported only at the quarterly frequency. The dangers of using low-frequency holdings data to proxy for mutual funds' trading activity are best illustrated in a recent study by Elton et al. (2010), who revisit some well known hypotheses, such as momentum trading, taxmotivated trading, window dressing, and tournament behavior, using holdings data observed at the monthly frequency instead of quarterly or semi-annual holdings data, and find that previously documented results change and in some cases reverse.

The database we employ in this paper, distributed by ANcerno Ltd., a private transaction costs analyst, contains detailed information on trades that approximately account for $8 \%$ of the total volume in CRSP in each of the years that we study. ${ }^{1}$ This dataset overcomes many of the limitations of previously employed proxies: It distinguishes between institutional and retail investors' trades; It enables us to measure total trading by institutional investors and the degree of correlated trading across institutions; It contains high-frequency data; And it does not ignore round-trip transactions.

We contribute to the literature in three different ways. First, we replicate the study of Koch et al. (2011) using institutional investors' trades data instead of holdings data. However, we control for mutual fund ownership in order to account for potential portfolio

\footnotetext{
${ }^{1}$ These data have been released to academic researcher and produced various studies including Goldstein et al. (2009), Chemmanur, He, and Hu (2009), Goldstein, Irvine, and Puckett (2011), Puckett and Yan (2011), Anand, Irvine, Puckett, and Venkataraman (2012), and Hu, McLean, Pontiff, and Wang (2010)
} 
choice effects. Second, as mentioned above, commonality in liquidity should be stronger when different institutional investors trade the same assets. To account for correlated trading across institutional investors, we follow the approach of Antón and Polk (2013). These authors find that stocks that are held by a larger number of common institutions ("connected" stocks) exhibit higher excess comovement in returns. Analogously, we study whether the degree of liquidity comovement between two stocks is associated with the number of common institutions trading in both stocks. Third, although we deal with the potential endogeneity of institutional portfolio choices by explicitly controlling for mutual fund ownership, the decision of which stocks to trade is also endogenous. Again, building on Antón and Polk (2013), we propose to exploit the mutual fund late trading and market timing scandal of 2003, which forced some families of funds to liquidate their positions, as an exogenous source of variation in institutional trading to study its effect on commonality in liquidity.

Our results suggest that institutional investor trading explains commonality in liquidity. The empirical evidence reveals a significant positive relationship between commonality in liquidity and institutional investor trading activity. Our findings are not driven by mutual fund ownership or other observable fund characteristics and are robust to different empirical specifications. Moreover, the results of the analysis of connected stocks are consistent with the idea that the mechanism for commonality in liquidity is correlated trading across institutions. Finally, the evidence from the 2003 mutual fund scandal suggests that there is a causal effect of institutional trading on liquidity comovement.

The remainder of the paper is organized as follows. In Section 2, we develop our main hypotheses and explain the methodology used to test the hypotheses. The data are described in section 3. Section 4 presents evidence of the relationship between commonality in liquidity and institutional trading activity. In Section 5, we study the relationship between common institutional trading and liquidity co-variation. Section 6 presents the results of our identification analysis. Robustness tests are included in Section 7. We conclude in Section 8. 


\section{Hypotheses and Methodology}

\subsection{Hypotheses}

Correlated trading across assets can arise if institutions' information-based strategies are correlated, as institutional investors react to the same information or as institutional investors infer information from the observed trading activity of others. Also, correlated trading can be the consequence of institutions responding to common liquidity shocks. In either case, if institutional investors trade at the same time and in the same direction, the increase in the demand for liquidity will affect dealer inventories across assets and will result in liquidity comovement (Chordia et al., 2000). Consistently with this reasoning, our first hypothesis captures the idea that commonality in liquidity should be more prevalent among stocks with a higher level of institutional trading activity.

Hypothesis 1: Stocks that are highly traded by institutional investors exhibit commonality in liquidity.

For institutional trading to cause liquidity commonality, institutions must demand liquidity at the same time across assets. When the shocks that motivate institutions' trades affect a larger number of institutions, we would expect an increase in the correlation of trading across institutions and therefore, more liquidity commonality among assets. For example, the mutual fund sector often experiences large market-wide inflows or outflows of money, which result in many funds demanding liquidity at the same time. This is so because mutual funds experiencing large outflows are often forced to liquidate positions in assets to meet redemptions as a consequence of the institutional constraints they face (Coval and Satafford, 2007; Jotikasthira et al., 2012; Zhang, 2010). Similarly, a mutual fund experiencing large inflows often must increase its existing positions in order to avoid large cash balances (Pollet and Wilson, 2008). In either case, many institutions will be forced to demand liquidity at the same time and this will affect market-wide asset liquidity. Therefore, we would expect the association between institutional trading and commonality in liquidity to be higher in periods of extreme aggregate 
flows of money into and out of mutual funds.

Hypothesis 2a: The effect of institutional investors' trading activity on commonality in liquidity is stronger in periods of large aggregate flows into/out of mutual funds.

It could be argued that mutual funds are better able to cope with money inflows than outflows. After all, increasing cash holdings as a response to inflows may be detrimental to fund performance but is feasible, whereas failing to redeem shares or borrowing is not an option for mutual funds facing outflows. While mutual funds could split their purchases and distribute them through time when facing money inflows, they will often be forced to liquidate positions soon when experiencing outflows. Therefore, we also consider the following variant of Hypothesis 2:

Hypothesis 2b: The effect of institutional investors' trading activity on commonality in liquidity is stronger in periods of flows of money out of mutual funds.

While we expect all assets traded by institutions to experience correlated trading, this correlation will be higher if assets are traded by the same institutions. Antón and Polk (2013) document a positive association between comovement of stock returns and the degree of connectedness between stocks through common mutual fund ownership. In particular, they forecast the cross-sectional variation in return correlation using the degree of shared ownership or the number of funds that hold a pair of stocks $i$ and $j$ in their portfolios: Pairs of stocks that are connected in this fashion exhibit more price comovement controlling for stock characteristics. Following the same reasoning and using the same approach, we hypothesize that stock connectedness through institutional trading explains commonality in liquidity.

Hypothesis 3: Commonality in liquidity is stronger among stocks that are connected through common institutional trading. 


\subsection{Variable Definitions}

Our primary measure of stock-level institutional trading is based on the fraction of firm $i$ 's shares traded by all institutions in our sample on day $d$. Specifically, for each stock, we construct a daily measure of aggregate institutional investor trading

$$
\text { Daily_ITrade }_{i, d}=\frac{\sum_{j=1}^{J} \text { sharestraded }_{i, j, d}}{\text { shrout }_{i, d}}
$$

where sharestraded $_{i, j, d}$ is the number of shares traded (buy and sell) in stock $i$ by institution $j$ on day $d$, shrout $t_{i, d}$ is the total number of shares outstanding of stock $i$ on day $d$. In our analysis we use the mean value of Daily_ITrade $i, d$ in quarter $t$, which we denote by ITrade $_{i, t}$.

We follow the literature and use Amihud (2002) illiquidity measure to proxy for stock daily illiquidity. The Amihud (2002) illiquidity measure is computed as the absolute value of stock $i$ 's return on day $d$ divided by the dollar volume of trading in stock $i$ on that day. ${ }^{2}$

$$
\text { illiq }_{i, d}=\frac{\left|r_{i, d}\right|}{\left|d v o l_{i, d}\right|}
$$

We use Amihud illiquidity in our study in two ways. First, we employ the change in Amihud (2002) illiquidity measure to estimate loadings of stock liquidity on market-wide liquidity as well as pair-wise liquidity comovement. Second, we add the level of Amihud illiquidity measure as an additional control in many specifications to account for the possible effect of liquidity level on commonality in liquidity. In particular, changes in Amihud illiquidity are computed as

$$
\triangle i l l i q_{i, d}=\ln \left[\frac{i l l i q_{i, d}}{i l l i q_{i, d-1}}\right]
$$

\footnotetext{
${ }^{2}$ Hasbrouck (2009) analyzes various price impact measures estimated on daily and intradaily data, and finds that Amihud (2002) is highly correlated with transaction-based measures. For instance, he finds that the correlation between Kyle's lambda and Amihud's measure is 0.82. Kyle (1985) lambda is first estimated by Brennan and Subrahmanyam (1996) using intraday trade and quote data. Brennan and Subrahmanyam (1996) estimate lambda by regressing trade-by-trade price change on signed transaction size. Lambda measures the price impact of a unit of trade size and, therefore, it is larger for less liquid stocks. Hasbrouck (2009) uses a similar method to estimate Kyle's lambda. Goyenko et al. (2009) report that Amihud's measure is comparable to intraday estimates of price impact such as Kyle's lambda.
} 
where $r_{i, d}$ is the return for stock $i$ in day $d$ and $d v o l_{i, d}$ is the dollar volume for stock $i$ in day $d$.

\subsection{Testing Methodology}

To test whether stocks with high institutional trading activity exhibit commonality in liquidity, we follow a two-step approach similar to that employed by Coughenour and Saad (2004) and Koch et al. (2011). In the first step, we estimate the individual stock liquidity co-variation with the liquidity of a portfolio of stocks with high institutional trading activity (value of ITrade in the top quartile of the cross-sectional distribution). In the second step, we test whether liquidity co-variation between individual stocks and the high ITrade portfolio is stronger among firms with high institutional trading.

More specifically, for each firm $i$ and quarter $t$ in our sample, we run a time series regression of daily changes in the Amihud illiquidity measure on the illiquidity of two portfolios: a high institutional trading portfolio containing all stocks in the top quartile of institutional trading activity as ranked at the end of the previous quarter, and a market portfolio containing all stocks:

$$
\triangle i l l i q_{i, d}=\alpha_{i, t}+\beta_{H I, i, t} \triangle i l l i q_{I T r a d e, d}+\beta_{m k t, i, t} \triangle i l l i q_{m k t, d}+\delta \text { controls }+\varepsilon_{i, d}
$$

We follow Chordia et al. (2000) and include as controls one lead and one lag changes in the two portfolio illiquidity variables, contemporaneous firm return squared, and lead, lag, and contemporaneous market returns. The squared stock return is included to proxy for volatility, which could be associated with liquidity. As in Chordia et al. (2000), for each regression we exclude firm $i$ from the market portfolio as well as from the high institutional trading portfolio. In order to minimize the effect of outliers, we winsorize observations that are in the top and bottom $1 \%$ of the stock's liquidity distribution.

Our first hypothesis is that the liquidity of stocks with high levels of institutional investor trading activity covaries more with that of other highly traded stocks. To test this hypothesis, we study whether estimated loadings on the high institutional trading portfolio are positively related to the level of institutional investors' trading in the cross section of stocks. Moreover, 
we regress $\beta_{H I}$ against the previous quarter institutional investors level of correlated trading measure, ITrade $e_{i, t-1}$, controlling for total market trading activity, MTrade $e_{i, t-1}$ computed as the total CRSP volume for stock $i$ divided by total shares outstanding, firm size and average illiquidity:

$$
\beta_{H I, i, t}=\alpha+b_{1} \operatorname{ITrade}_{i, t-1}+b_{2} \operatorname{MTrade}_{i, t-1}+b_{3} \ln \left(\operatorname{size}_{i, t-1}\right)+b_{4} i l l i q(\operatorname{avg})_{i, t-1}+\varepsilon_{i, t}
$$

Hypothesis 2 a predicts that the impact of institutional investors' trades should be greater in periods of high absolute flows. We follow Koch et al. (2011) and compute aggregate mutual fund flows for each quarter using data from CRSP Mutual Fund Survivorship Bias Database. In particular, we compute the net dollar flow into or out of equity mutual funds. We then divide this amount by the dollar value of the market at the beginning of the quarter. From the resulting time series, we calculate a dummy variable, extremeflow, that equals one if aggregate flows in a quarter are in the top or bottom $10 \%$ of all quarters, and zero otherwise. Net flows are signed, so the bottom (top) $10 \%$ is comprised of the largest net outflow (inflow) quarters. To test Hypothesis 2b, we also create another dummy variable, negflow, that equals one if aggregate flows are negative, and zero otherwise. Each of these dummy variables is interacted with ITrade $_{i, t-1}$ and $M$ Trade $_{i, t-1}$ and included in the regression specifications.

To test our third Hypothesis, we follow the approach proposed by Antón and Polk (2013) and look at pairs of stocks connected through institutional trading. More specifically, we study whether the number of institutional investors trading simultaneously in two stocks predicts the pair-wise liquidity co-variation between the stocks, controlling for similarity in industry, size, book-to-market ratio, and momentum characteristics. In particular, we estimate

$$
\begin{aligned}
\triangle i l l i q_{i, t+1} \triangle i l l i q_{j, t+1} & =\alpha+\beta_{f} F_{i j, t}^{*}+\beta_{s} D I F F_{-} S I Z E_{i j, t}^{*}+\beta_{b} D I F F_{-} B E M E_{i j, t}^{*} \\
& +\beta_{m} D I F F_{-} M O M_{i j, t}^{*}+\beta_{k} N U M_{-} S I C_{i j, t}^{*}+\beta_{s 1} S I Z E 1_{i j, t}^{*} \\
& +\beta_{s 2} S I Z E 2_{i j, t}^{*}+\beta_{s 12} S I Z E 1 S I Z E 2_{i j, t}^{*}+\varepsilon_{i j, t}
\end{aligned}
$$

where $F_{i j, t}$ is the number of institutions that trade both stock $i$ and $j$ on month $t$. As in Antón and Polk (2013) for each cross section, we calculate the normalized rank transformation 
of $F_{i j, t}$ (so the variable has zero mean and unit standard deviation), which we denote as $F_{i j, t}^{*}$. To control for commonality in liquidity induced by similar stock characteristics, we follow Antón and Polk (2013) and for each month we first calculate every stock's percentile ranking on a particular characteristic. The measures of similarity, DIFF_SIZE, DIFF_BEME, and DIFF_MOM, are just the negative of the absolute difference in percentile ranking across a pair for a particular characteristic. We expect higher liquidity co-variation between two stocks if they have a higher similarity in these characteristics. In addition, one would expect liquidity of firms in similar industries to covary strongly, all else equal. To capture that similarity, we use the same approach as Antón and Polk (2013) and measure industry similarity as the number of consecutive SIC digits that are equal for a given pair, NUM_SIC. As with our institutional connectedness measures, we use the normalized rank transforms of these variables, which we denote with an asterisk superscript. As institutional trading is correlated with size, we also create very general size controls based on the normalized rank transformation of the percentile market capitalization of the two stocks, SIZE1 and SIZE2 (where we label the larger stock in the pair as the first stock), and the interaction between the two market capitalization percentile rankings.

We estimate these coefficients using the approach of Fama and McBeth (1973). All independent variables are cross-sectionally demeaned as well as normalized to have unit standard deviation so that the intercept $\alpha$ measures the average cross-sectional effect and the regression coefficients are easily interpreted. We calculate Newey-West standard errors of the Fama-MacBeth estimates that take into account autocorrelation in the cross-sectional slopes up to four lags.

\section{Data}

We obtain institutional transaction order-level data from ANcerno Limited for the period from January 1, 1999 to September 30, 2011. ANcerno is a leading consulting firm that provides institutional investors with transaction cost analysis and trading technology services. ANcerno data cover the equity transactions of ANcerno' clients, a large number of institutional investors including pension plan sponsors, such as CALPERS, the Commonwealth of Virginia, and 
the YMCA retirement fund, as well as institutional money managers, such as Massachusetts Financial Services, Putman Investments, Lazard Asset Management, and Fidelity. The data offer significant advantages over other high-frequency trading data that make them uniquely suited for investigating institutional investor trading and commonality in liquidity relationship. The critical attribute of the data set from the perspective of our study is that each observation includes information on the unique identity of each institution, unique stock identification variable stockkey as well as cusip, and ticker, the transaction price, date and time stamps for the order, execution price, number of shares executed, and whether the execution is a buy or sell. As per ANcerno's officials, the database captures the complete history of all transactions of the institutions as long as they remain in the sample. The data do not reveal identities of institutions in order to protect the privacy of ANcerno's clients, but the unique client code facilitates identification of an institution both in the cross-section and through time. Since ANcerno is proprietary database, survivorship and selection bias issues are potential concerns. While the data may suffer selection bias, the survivorship bias is not a concern (Puckett and Yan, 2011).

Summary statistics for Ancerno's trade data and stock characteristics are reported in Table 1. The sample contains a total of 1,142 institutions that are responsible for about 205 million trades involving approximately $\$ 33$ trillion (1110 billion shares) in trading volume. On average, this trading activity accounts for approximately $8 \%$ of the dollar value of trading volume as reported by CRSP during the 1999 to 2011 sample period. ${ }^{3}$ Since total institutional investor trading accounts for $80 \%$ of CRSP trading volume, we estimate that ANcerno clients are responsible for $10 \%$ of all institutional trading volume. Table 1 reveals several notable time series patterns in trading of institutional investors in our sample. The number of institutions in the database peaks in 2002 and declines towards the end of sample period. The total number of stocks traded by ANcerno clients declines from 4,855 in 1999 to 3,331 in 2011. The average dollar volume varies between a minimum of $\$ 427,977$ in 2000 and a maximum of $\$ 96,935$ in

\footnotetext{
${ }^{3}$ We calculate the ratio of ANcerno trading volume to CRSP trading volume during each day of the sample period. We include only stocks with sharecode equal to 10 or 11 in our calculation. In addition, we divide all ANcerno trading volume by two, since each individual ANcerno client constitutes only one side of a trade. We believe this estimate represents an approximate lower bound for the size of the ANcerno database (Puckett and Yan, 2011).
} 
2011. The median dollar volume ranges from $\$ 58,025$ in 1999 to $\$ 4,206$ in 2007.

To complement ANcerno trade data, we collect stock market data such as stock returns, share prices, trading volume, and number of shares outstanding from CRSP . Summary statistics for the sample of stocks traded by ANcerno institutions are reported in Panel C of Table 1. We report the cross-sectional average of stock characteristics for the full sample and by firm size quintile. The average market capitalization of securities traded by ANcerno institutions is $\$ 6.83$ billion, while the mean illiquidity is 0.0051 . Moreover, we report that our sample of stocks have average turnover of $245.6 \%$ per year. In addition, we find that the average illiquidity of stocks in the bottom size quintile is 0.0182 , while the corresponding number for stocks in the top size quintile is only 0.0002. Small stocks experience an average trading volume of 2.15 (million) shares, while the large stocks' average trading volume is 33.7 (million) shares.

Finally, we use CRSP Survivorship Bias-Free mutual fund database to collect data on mutual fund total net assets and equity holdings for the period between 1999-2011.

To obtain the required data for our empirical analysis and minimize observations with errors, we choose these filtering criteria: (1) We delete orders with order volume greater than the stock's CRSP volume on the execution date; (2) We follow Chordia et al. (2000) and retain class A stocks and remove preferred stocks or shares, warrants, rights, derivatives, trusts, closedend investment companies, American depositary receipts, units, shares of beneficial interest, holdings and realty trusts; (3) We exclude those names where the average price of the firm over the year is below $\$ 2$ and above $\$ 200$. This is important because daily variation in liquidity for firms outside these price ranges can be very high, due to either binding tick constraints, discreteness in price changes, or very low trading volume. To estimate liquidity betas, we require a minimum of 40 observations per quarter. Our filtering criteria result in 3,297 firms in the sample. 


\section{Empirical Results}

\subsection{Institutional Investor Trading and Commonality in Liquidity}

To test Hypothesis 1, we need to estimate liquidity betas from time series regressions of daily changes in liquidity on the changes in liquidity of a portfolio of highly-traded stocks and the market portfolio. Table 2 reports yearly average sample statistics for both the market and the high-institutional-trading portfolios as well as the estimated coefficients of interest. The left-hand side of Table 2 shows the yearly average of the liquidity beta coefficients with respect to the portfolio of highly traded stocks, the percentage of beta coefficients that are positive, the percentage of coefficients that are significant (at the $5 \%$ level), as well as a t-statistic on the sample of beta coefficients that are significant in that year. The table also reports the average firm size, the number of stocks in both portfolios and the average illiquidity.

Time-series regression estimates reveal that an individual stock's liquidity co-varies with the liquidity of a portfolio of stocks that are highly traded by institutional investors, controlling for information inducing co-variation with market liquidity. However, the institutional-liquidity beta is roughly one-half the size of the market-liquidity beta. We find that the magnitude and percentage of positive institutional liquidity betas are lowest at the beginning of our sample and increase toward the end of sample period, the opposite patterns are observed for market liquidity betas. It is interesting to compare our results with those of Koch et al. (2011). Koch et al. (2011) use the change in the Amihud (2002) illiquidity measure (same as in our study) and the fraction of shares outstanding held by mutual funds to proxy for correlated trading (we use actual institutional trades). As in Koch et al. (2011), Table 2 shows that relatively few of the liquidity betas are significantly different from zero at the $5 \%$ level. This is probably due to short sample length of time-series regressions. ${ }^{4}$ The signs and significance of the commonality coefficients are similar to those obtained in Koch et al. (2011). While the full sample average of $\beta_{H I}$ in our sample is smaller, the degree of individual liquidity variation explained is higher. As in Koch et al. (2011), the average firm size in the institutional investor portfolio is smaller

\footnotetext{
${ }^{4}$ In unreported tests, using the full available time series to estimate liquidity betas, we find that $63 \%$ of institutional investors liquidity beta and $80 \%$ of market liquidity betas betas are positive, with $20 \%$ and $33 \%$ significantly different from zero at the $5 \%$ level, respectively.
} 
than the average size of firms in the market portfolio, consistent with findings of Blume and Keim (2012), who document that in the recent years institutional investors tend to overweight smaller stocks and underweight larger stocks relative to market weights. Institutional trading on average has increased over the entire sample of stocks through time. For the stocks in the top quartile of institutional investors trading has increased from $0.14 \%$ in 1999 to $0.22 \%$ in the 2009. Stocks were less liquid in the 1999 relative to the later period. The decrease in illiquidity is most pronounced among the stocks in the highest quartile of institutional investors trading with average illiquidity lower than the average illiquidity of the stocks in the market portfolio in all quarters. This result indicates that institutional investors prefer liquid stocks consistent with findings of earlier studies (Falkenstein, 1996).

To test Hypothesis 1, we regress estimated $\beta_{H I}$, our measure of commonality in liquidity, against the previous quarter's institutional trading ITrade $_{i, t-1}$ controlling for firm characteristics, such as size and average illiquidity. In addition, we include time dummies and cluster the standard errors at the firm level. Estimation results are reported in Panel A of Table 3. Column (1) of this table reports the results of the full sample pooled OLS regression of $\beta_{H I}$ against institutional trading, time dummies and total market trade. The coefficient on $\beta_{H I}$ is positive and statistically significant at conventional significance levels, which suggests that stocks with high institutional trading activity exhibit strong liquidity covariation.

Prior studies find that institutional investors select stocks based on characteristics that are correlated with future liquidity (Del Guercio, 1996; Falkenstein, 1996). In column (2) we add firm size and average illiquidity as additional controls. The coefficient on institutional investors' correlated trading remains positive and highly significant and the magnitude is slightly higher than the estimated coefficient without controls. This result is also economically significant: A one standard deviation increase (0.10) in institutional investor trading is associated with a 0.08 increase in $\beta_{H I}$, which equals a $33 \%$ increase relative to its mean value. These findings are similar to those obtained by Koch et al. (2011), who document that a one standard deviation increase in mutual fund ownership is associated with a 0.08 increase in their liquidity beta, a $27 \%$ increase from its mean.

One possible concern is whether our findings are driven by institutional investors' preferences 
for stock characteristics other than size and liquidity that could be correlated to $\beta_{H I}$. To control for time-invariant unobserved heterogeneity, we include firm fixed effects in Column (3). The last two columns of Table 3 use different assumptions on the structure of the error term: Column (4) employs standard errors clustered at firm level and time level; and Column (5) reports the results of Fama-MacBeth (1973) regressions. Under all specifications, we find a positive relationship between liquidity beta with respect to the high institutional investor portfolio and trading by institutional investors. The relationship is both economically and statistically significant.

Koch, Ruenzi, and Starks (2011) provide empirical evidence that stocks with high mutual fund ownership exhibit strong liquidity comovements. Institutional trading correlates with institutional ownership which, in turn, captures endogenous institutional portfolio choices that could be related to commonality in liquidity. To account for that possibility, we control for mutual fund ownership in column (6). The results indicate that mutual fund ownership has explanatory power with respect to commonality in liquidity even when our proxy for institutional trading is included among the regressors. However, the association between our measure of institutional trading and liquidity commonality is still large and highly significant, suggesting that both variables capture different determinants of commonality in liquidity. This result has two possible not mutually exclusive interpretations. First, it could be that mutual fund ownership correlates with some institutions' portfolio choice determinants that are associated with liquidity commonality. Alternatively, mutual fund ownership could capture the effect of mutual funds' trading as distinct from that of other institutions.

In Panel B of Table 3 , we replace $I T r a d e_{i, t-1}$ with $D_{\text {ITrade }}$, a dummy variable that equals one if institutional trading is in the top quartile in the prior quarter, and zero otherwise. The results of Column (2) in Panel B indicate that stocks in the top quartile of institutional investor trading in the previous quarter have a $\beta_{H I}$ in the next quarter that is 0.17 higher than those outside the top quartile. This is a large economic effect given the unconditional mean $\beta_{H I}$ of 0.24. The estimated coefficient on this indicator variable is positive and statistically significant in all other specifications, too.

In Table 4, we reexamine the relationship between commonality in liquidity and institutional 
trading activity for sub-samples obtained by dividing the sample by size quartiles, average illiquidity quartiles, positive and negative market-return quarters, and sub-periods. The results for sub-samples based on size and illiquidity are presented in Panels A and C of Table 4. The first four columns show a significant positive relationship between institutional trading and commonality in liquidity in all size sub-samples. Also, there exists a strong positive relationship between institutional trading and commonality in liquidity in all liquidity subsamples, except for the most illiquid stocks (last column). In contrast, the coefficient on mutual fund ownership is positive and significant only for the two largest size sub-samples and the two most liquid subsamples. This finding is consistent with mutual fund ownership being associated with stock characteristics that are correlated with liquidity commonality.

Panels B and D report the results for different sub-periods and for up- and down-markets. The first three columns show that the association between mutual fund ownership and liquidity commonality is present in all sub-periods. However the magnitude of the coefficient of this relationship varies over time. In the last two columns we split the sample in up- and downmarket quarters and find a strong association in both market regimes. The coefficient on ITrade is larger in quarters with positive market returns, 130.6 with a t-statistic of 5.95, as opposed to 98.35 with a t-statistic of 6.70 in quarters with negative market returns. Nevertheless, the difference between the coefficients is not statistically significant.

Overall, these findings provide strong evidence that stocks with high institutional investor trading are characterized by strong liquidity comovement. This finding is not driven by institutions' portfolio choices, which gives further credence to the interpretation of the findings

of Koch et al. (2011). The effect is robust to various assumptions regarding unobserved heterogeneity, independence of observations, and functional form, as well as a variety of subsamples based on size, illiquidity and market conditions.

\subsection{Aggregate Fund Flows}

In the previous subsection, we provide evidence that stock liquidity comovement is associated with institutional trading activity. As argued in Section 2, we expect stronger correlated trading when a large number of institutions are forced to demand liquidity. To test Hypotheses 2a and 
2b, we follow Koch et al. (2011) and use aggregate fund flows as a proxy for market-wide shocks to the institutions' demand for liquidity. More specifically, in each quarter we aggregate fund flows to compute the net dollar flow into or out of equity mutual funds. We compute the dollar net money flow into fund $i$ in month $t$ as:

$$
D O L L A R \_F L O W_{i, t}=T N A_{i, t}-T N A_{i, t-1}\left(1+R_{i, t}\right)
$$

where $T N A_{i, t}$ is the Total Net Assets of fund $i$ in month $t$ and $R_{i, t}$ is the fund return over the period $t-1$ to $t$, as reported in the CRSP Mutual Fund Database. To compute the quarterly flows, we sum the dollar flows and divide them by $T N A$ at the end of the previous quarter.

In Table 5, we report the results of estimating (2) with interactions of ITrade and MTrade with two dummies: an extreme-flow dummy that equals one if the quarter is in the top and bottom $10 \%$ of the time series distribution of flows; and a negative-flow dummy that equals one for quarters with negative net flows. Column (1) shows that the impact of institutional trading on commonality in liquidity is much stronger during periods of extreme net flows than in normal periods. Specifically, the coefficient on ITrade is 54.15 in quarters without extreme flows compared to $54.15+40.27=94.42$ in quarters with extreme flows. In column (2) we include the interaction of MTrade with extremeflow as an additional control. Although, the estimated coefficient on the interaction term is positive but small and not statistically significant, the coefficient on the interaction with ITrade becomes smaller and only significant at the $10 \%$ level.

Columns (3) and (4) report the results when ITrade and MTrade are interacted with the negative-flow dummy. In contrast to the results of Koch et al. (2011), our findings are not consistent with the impact of institutional trading on commonality in liquidity being more pronounced when mutual funds experience outflows.

In column (5), we include both mutual fund ownership and an interaction term of mutual fund ownership with the extreme-flow dummy. The coefficient on the interaction term between ITrade and the extreme-flow dummy is no longer significant. Moreover, the interaction term between mutual ownership and the extreme-flow dummy is not significant either. In column (6), we include an interaction term between mutual fund ownership and the negative flow dummy. 
Interestingly, mutual fund ownership is no longer significant and the interaction term between mutual fund ownership and the negative-flow dummy is highly significant, suggesting that the explanatory power of mutual fund ownership with respect to commonality in liquidity detected in Table 3 is entirely due to quarters with negative flows.

Therefore, in contrast to Koch et al. (2011), we do not find evidence that the link between institutional activity and commonality in liquidity is stronger in periods of extreme flows or negative flows. One possible interpretation of these results is that in periods of extreme flows or negative flows, the level of trading by institutions increases, but not the degree of correlation in trading activity across institutions. Consistently with this explanation, the reason why Koch et al. (2011) find a stronger association between institutional ownership and commonality in liquidity in periods of extreme and negative flows is because institutional trading activity increases in those periods and not because trading becomes more correlated across institutions in those periods. Since the fluctuations in the level of trading are already captured by our proxy for institutional trading activity, the interaction term with mutual fund flows is not significant. The fact that the interaction term between mutual fund ownership and the negative flow dummy has a significant effect is consistent with the idea that the mutual fund ownership variable also captures the distinct effect of mutual funds' trading activity, and not just portfolio choice determinants.

\section{Common Trading}

To test our third hypothesis, pairs of stocks connected through common institutional trading exhibit higher commonality in liquidity, we follow an approach analogous to that proposed by Antón and Polk (2013). In particular, we form pairs of common stocks (share codes 10 and 11) from NYSE, AMEX and NASDAQ whose market capitalization is above one billion and we require firms to have at least 200 observation per year. We choose this filtering criteria to limit the number of pairs. Table 6 reports the number of stocks, pairs of stocks, and institutions trading those stocks during each year. Table 7 reports the extent of institutional trading. For the entire sample period, the median number of institutions per traded stock is 121 , while the median number of stocks traded by each institution is 566 . 
We report the number of common institutions for a pair of stocks in Table 8. All stock pairs have at least one active institutional trading in common and the median pair has 14 institutional investors in common. The table also shows that the number of common institutional tradingbased connections between stocks in our sample has increased over the period we study. In 1999, the median number of common institutional trading connections was 6 . In 2009, the median number of trading connections was 24 , although this figure is only 14 in the last year of our sample period.

Table 9 reports estimation results. In column (1), we estimate a specification with the number of institutions trading in both stocks as a regressor and find a positive and statistically significant link between that variable and liquidity comovement between two stocks. A change of one standard deviation in the degree of common trading results is associated with a $7.3 \%$ increase in the expected product of liquidity changes relative to the average degree of covariation.

The ability to forecast differences in liquidity comovement using institutional connectedness would be expected if the predictability simply reflects the fact that the institutions choose to trade stocks that are similar even if institutional trading is not associated with liquidity commonality. Therefore, we include four variables to control for stock similarity. The results of this analysis are reported in columns (2)-(4) of Table 9. Control variables are normalized to have a standard deviation of one and transformed (in the case of size, book-to-market, and momentum) so that higher values indicate greater style similarity. The coefficient on our measure of common institutions is similar to that found in column (1), although comovement in stock liquidity also seems to be strongly associated with stock similarity. The coefficient on common institutional trading has the strongest economic significance among all variables under consideration.

\section{The Mutual Fund Scandal of 2003}

Thus far, our results indicate that commonality in liquidity is higher for stocks that are highly traded by institutional investors. We also show that our results are robust to different specifications. As we estimate these effects using lag ITrade at the quarterly frequency, an 
important issue is the extent to which we can make statements about the causal nature of the relationship between ITrade and $\beta_{H I}$. Two concerns are in order. First, a third variable, such as a specific stock characteristic, could be causing both institutional trading in a certain group of stocks and commonality in liquidity. Controlling for observable stock characteristics and time-invariant unobservable characteristics is not enough if the third variable is not observable and varies through time. Second, a positive relation between ITrade and $\beta_{H I}$ is consistent with commonality in liquidity causing institutional trading. For instance, a market-wide deterioration of liquidity risk could lead investors to unwind their positions in order to reduce future liquidity risk. To address this concern, this section deals with the potential consequences of endogeneity.

Building on Antón and Polk (2013), we propose to exploit a natural experiment based on the mutual fund scandal that occurred in September 2003. In the last quarter of 2003, 25 fund families settled allegations of illegal trading that included market timing and late trading. Affected funds experienced significant outflows as a consequence of the scandal. Kisin (2011) documents that the funds of affected families continued to experience outflow until the year of 2007. The estimated losses for the affected funds are $14.1 \%$ within a year and $24.3 \%$ in two years since the scandal broke. McCabe (2009) estimates that the losses 36 months after the scandal to be $37 \%$ of the assets under management for the implicated fund families. We argue that capital flows arising from this scandal are exogenous, and so is the excess trading experienced by stocks more widely held by mutual funds.

More specifically, we instrument institutional trading on a given stocks with the fraction of shares of that stock owned by all scandal-affected funds divided by the fraction of shares owned by all funds one quarter before the scandal broke. We then use two-stage least-squares estimation. Column (1) of Table 10 shows the results of the first-stage regression, ITrade on fraction and various controls used in regression (2). The coefficient on fraction is positive and highly significant. Column (2) of table 10 presents the results of the second-stage regression, where the dependent variable is $\beta_{H I, i t+1}$. The coefficient is positive and significant at the $5 \%$ level. 


\section{Robustness Tests}

The empirical evidence thus far suggests that stocks that are highly traded by institutional investors exhibit strong commonality in liquidity. The relationship between $\beta_{H I}$ and ITrade is robust to different model specifications. In this section, we show that the particular specification of the first-step time-series regression is not crucial to our main results. In particular, we address the concerns arising from using Amihud illiquidity measure as a proxy for stock liquidity. For instance, the liquidity co-variation that we document could be induced by commonality in (absolute) returns, not necessarily by comovements in the ratio of absolute returns to dollar volume. We first show that our results are not driven by returns or volatility comovement, and then demonstrate that our results are not specific to the structure of our first stage estimation.

We follow Koch et al. (2011) and address the impact of return comovements and volatility comovements in three different ways. First, we estimate the covariance between individual stock return and the value-weighted return of the high institutional trading portfolio and add it as an additional control in the regression equation (2). We refer to this variable as institutional return beta. The results of these regressions are presented in Panel A Table 11. Column (1) reports the results of equation (2) after adding institutional return beta as an additional control, consistent with Koch et al. (2011) we find that institutional return beta has a strong positive impact on $\beta_{H I}$. This shows that commonality in return (information affecting return on high institutional trading stocks) has an impact on commonality in liquidity among these stocks. Nevertheless, the positive impact of institutional trading activity on $\beta_{H I}$ still remains highly significant. Second, we run our base regression (2) on sub-samples based on institutional return beta quartiles to capture any potential non-linear relationship between liquidity beta and institutional return beta. The results of these regression are reported in column (2) through column (5). We find that our main findings hold in all sub-samples as indicated by highly significant and positive estimate for the impact of ITrade on $\beta_{H I}$. Third, we alter the first step time series regression (1) by adding the return of high institutional trading stocks portfolio to account for the potential impact of covariation between stock liquidity and the return of highly trade stocks portfolio. Column (6) reports the result of equation (2) using $\beta_{H I}$ from the modified first stage model as dependent variable. We still find a positive significant impact of 
ITrade on $\beta_{H I}$.

Furthermore, we address the concern that our findings could be driven by the fact that common movements in volatility of stocks traded to a high degree by institutional investors lead to higher liquidity commonality. We conduct a test similar to that described above, replacing returns in the time-series regressions with return squared as a proxy for volatility. We report the result of this additional analysis in Panel B of Table 11. We find that results obtained from the standard second stage regression do not change: We still find positive significant impact of ITrade on $\beta_{H I}$.

Table 12 varies the definition of common trading for our benchmark specification of table 9. We first replace the number of common institutions, $F_{i j, t}$, with the total dollar volume by all common institutions of the two stocks scaled by number of shares outstanding of the two stocks, $F_{i j, t}^{T}$. Our next alternative is to measure the common trading by the the total cross product of dollar volume by all common institutions of the two stocks scaled by number of shares outstanding of the two stocks, $F_{i j, t}^{C T}$. Both alternative measures of common trading forecast the cross-sectional variation in realized changes in liquidity cross-products.

\section{Conclusions}

In this paper, we reevaluate the empirical evidence that institutional investors' trading activity induces the liquidity of stocks to move together. We overcome the limitations of previously employed proxies and establish a direct link between institutional trading activity and liquidity commonality by using data on actual institutional investor trades obtained from ANcerno Ltd for the 1999-2011 period. Consistent with the interpretation of the findings of Koch et al. (2011), our results suggest that the trading activity of institutional investors is an important factor in explaining commonality in liquidity. These results are not driven by institutional investors' portfolio selection and are robust to a variety of specifications.

However, contrary to our expectation, we do not find evidence that the association between institutional trading and commonality in liquidity strengthens in periods of extreme or negative flows of money into and out of mutual funds. A possible interpretation of these results is that in periods of extreme flows or negative flows, the level of trading by institutions increases, but not 
the degree of correlation in trading activity across institutions. Since our variable of interest in institutional trading, the effect of flows on commonality in liquidity is already taken into account.

We also find evidence that the impact of institutional trading on commonality in liquidity is due to correlated trading. In particular, the liquidity of pairs of stocks that are connected through their common active institutional trading covary more together, controlling for stock characteristics.

Finally, when we instrument trading with the fraction of a stock's share owned by funds affected by the 2003 scandal and focus on the months following the scandal, we find evidence of a causal link from institutional trading to commonality in liquidity.

The results of our study are interesting both from an academic and a practical point of view. First, we document that an increase in institutional investors' trading activity is associated with higher commonality in liquidity. This has implications for portfolio managers following active strategies who might consider avoiding stocks whose trading is dominated by institutional investors. Second, our results should be taken as a warning against the large-scale effects of financial institutions demanding liquidity for similar motives and therefore at the same time.

\section{References}

Acharya, V. and L. Pedersen (2005). Asset pricing with liquidity risk. Journal of Financial Economics 77(2), 375-410.

Amihud, Y. (2002). Illiquidity and stock returns: cross-section and time-series effects. Journal of Financial Markets 5(1), 31-56.

Amihud, Y. and H. Mendelson (1986). Asset pricing and the bid-ask spread. Journal of financial Economics 17(2), 223-249.

Anand, A., P. Irvine, A. Puckett, and K. Venkataraman (2012). Performance of institutional trading desks: An analysis of persistence in trading costs. Review of Financial Studies 25(2), $557-598$. 
Antón, M. and C. Polk (2013). Connected stocks. Journal of finance, Forthcoming.

Blume, M. and D. Keim (2012). Institutional investors and stock market liquidity: Trends and relationships. Working Paper.

Brennan, M. and A. Subrahmanyam (1996). Market microstructure and asset pricing: On the compensation for illiquidity in stock returns. Journal of Financial Economics 41(3), 441-464.

Brunnermeier, M. and L. Pedersen (2009). Market liquidity and funding liquidity. Review of Financial Studies 22(6), 2201-2238.

Chemmanur, T., S. He, and G. Hu (2009). The role of institutional investors in seasoned equity offerings. Journal of Financial Economics 94(3), 384-411.

Chordia, T., R. Roll, and A. Subrahmanyam (2000). Commonality in liquidity. Journal of Financial Economics 56(1), 3-28.

Comerton-Forde, C., T. Hendershott, C. Jones, P. Moulton, and M. Seasholes (2010). Time variation in liquidity: The role of market-maker inventories and revenues. The Journal of Finance 65(1), 295-331.

Cornett, M., J. McNutt, P. Strahan, and H. Tehranian (2011). Liquidity risk management and credit supply in the financial crisis. Journal of Financial Economics 101(2), 297-312.

Coughenour, J. and M. Saad (2004). Common market makers and commonality in liquidity. Journal of Financial Economics 73(1), 37-69.

Coval, J. and E. Satafford (2007). Asset fire sales (and puchases) in equity markets. Journal of financial economics 86(2), 479-512.

Del Guercio, D. (1996). The distorting effect of the prudent-man laws on institutional equity investments. Journal of Financial Economics 40(1), 31-62.

Elton, E. J., M. J. Gruber, C. R. Blake, Y. Krasny, and S. O. Ozelge (2010). The effect of holdings data frequency on conclusions about mutual fund behavior. Journal of Banking \& Finance 34(5), 912-922. 
Falkenstein, E. G. (1996). Preferences for stock characteristics as revealed by mutual fund portfolio holdings. The Journal of Finance 51(1), 111-135.

Goldstein, M., P. Irvine, E. Kandel, and Z. Wiener (2009). Brokerage commissions and institutional trading patterns. Review of Financial Studies 22(12), 5175-5212.

Goldstein, M., P. Irvine, and A. Puckett (2011). Purchasing ipos with commissions. Journal of Financial and Quantitative Analysis 46(5), 1193.

Goyenko, R., C. Holden, and C. Trzcinka (2009). Do liquidity measures measure liquidity? Journal of Financial Economics 92(2), 153-181.

Hameed, A., W. Kang, and S. Viswanathan (2010). Stock market declines and liquidity. The Journal of Finance 65(1), 257-293.

Hasbrouck, J. (2009). Trading costs and returns for us equities: Estimating effective costs from daily data. The Journal of Finance 64(3), 1445-1477.

Hasbrouck, J. and D. Seppi (2001). Common factors in prices, order flows, and liquidity. Journal of financial Economics 59(3), 383-411.

Hu, G., R. D. McLean, J. Pontiff, and Q. Wang (2010). Do fund managers try to mislead investors? evidence from year-end trades. Technical report, Working Paper, Babson College.

Jotikasthira, C., C. Lundblad, and T. Ramadorai (2012). Asset fire sales and purchases and the international transmission of funding shocks. The Journal of Finance 67(6), 2015-2050.

Kamara, A., X. Lou, and R. Sadka (2008). The divergence of liquidity commonality in the cross-section of stocks. Journal of Financial Economics 89(3), 444-466.

Karolyi, G. A., K.-H. Lee, and M. A. Van Dijk (2012). Understanding commonality in liquidity around the world. Journal of Financial Economics 105(1), 82-112.

Kisin, R. (2011). The impact of mutual fund ownership on corporate investment: Evidence from a natural experiment. Working Paper. 
Koch, A., S. Ruenzi, and L. Starks (2011). Commonality in liquidity: a demand-side explanation. Technical report, Working paper, University of Texas.

Korajczyk, R. and R. Sadka (2008). Pricing the commonality across alternative measures of liquidity. Journal of Financial Economics 87(1), 45-72.

Kyle, A. S. (1985). Continuous auctions and insider trading. Econometrica 53(6), 1315-1336.

McCabe, P. (2009). The economics of the mutual fund trading scandal. Working Paper.

Pastor, L. and R. Stambaugh (2003). Liquidity risk and expected stock returns. The Journal of Political Economy 111(3), 642-685.

Pollet, J. M. and M. Wilson (2008). How does size affect mutual fund behavior? The Journal of Finance 63(6), 2941-2969.

Puckett, A. and X. Yan (2011). The interim trading skills of institutional investors. The Journal of Finance 66(2), 601-633.

Zhang, H. (2010). Asset fire sales, liquidity provision, and mutual fund performance. Working Paper, Nanyang Technological University. 


\section{Table 1: Descriptive Statistics for ANcerno Institutional Trading Data and Stock Characteristics}

This table reports summary statistics of institutional trading data obtained from ANcerno Ltd. The sample contains the trades of 1,142 institutions during the period from January 1, 1999 to September 30, 2011. We restrict our sample to stocks where ANcerno volume is less than or equal to the total daily trading volume reported in CRSP. Panel A shows descriptive statistics for the full sample of institutional trading data. Panel B reports descriptive statistics for year subsamples. Panel $\mathrm{C}$ reports descriptive statistics for stocks traded by ANcerno institutions. We obtain share prices, total shares outstanding, stock returns, and trading volume from the CRSP stock database. Our sample includes only common stocks (those with a sharecode of 10 or 11 in CRSP). Amihud illiquidity measure is constructed as the average of daily ratios between absolute return and dollar trading volume. We compute stock characteristics each quarter. Market capitalization is as of the end of the previous quarter. All other stock characteristics are measured based on the 12-month period until the end of the previous quarter. Firm-size quintile breakpoints are computed for the stocks in our sample. We report the quarterly cross sectional averages for all stock characteristics in each size-quantile.

\begin{tabular}{|c|c|c|c|c|c|c|c|c|c|}
\hline \multirow[b]{2}{*}{ Panel A: } & $\begin{array}{l}\text { No. } \\
\text { Inst. }\end{array}$ & No. & \multicolumn{2}{|c|}{ No. $\quad$ Shares } & Dollar & \multicolumn{4}{|c|}{$\begin{array}{l}\text { Ave. Shares Med. Shares Ave. Dollar Med. Dollar } \\
\text { Vol. per Tr. Vol. per Tr. Vol. per Tr. Vol. per Tr. }\end{array}$} \\
\hline & 1142 & 7800 & 205.68 & 1110 & 32950 & 5395.65 & 300 & 160165.1 & 9396 \\
\hline \multicolumn{10}{|l|}{$\begin{array}{l}\text { Panel B: } \\
\text { By year }\end{array}$} \\
\hline 1999 & 379 & 4855 & 4.00 & 35 & 1550 & 8739 & 1600 & 388,477 & 58025 \\
\hline 2000 & 370 & 4761 & 5.42 & 52 & 2320 & 9612 & 1500 & 427,977 & 54500 \\
\hline 2001 & 398 & 4176 & 6.82 & 75 & 2270 & 11052 & 1400 & 332,664 & 38523 \\
\hline 2002 & 424 & 3942 & 9.17 & 100 & 2390 & 10905 & 1300 & 260,799 & 30132 \\
\hline 2003 & 401 & 3993 & 7.92 & 71 & 1750 & 8907 & 1020 & 220,640 & 27103 \\
\hline 2004 & 404 & 4202 & 16.39 & 117 & 3320 & 7113 & 700 & 202,353 & 20361 \\
\hline 2005 & 376 & 4050 & 14.75 & 94 & 2930 & 6399 & 400 & 198,372 & 13338 \\
\hline 2006 & 399 & 4062 & 24.63 & 103 & 3270 & 4185 & 200 & 132,652 & 6526 \\
\hline 2007 & 377 & 4114 & 31.02 & 103 & 3590 & 3323 & 100 & 115,614 & 4206 \\
\hline 2008 & 333 & 3817 & 26.20 & 122 & 3450 & 4672 & 200 & 131,796 & 5961 \\
\hline 2009 & 322 & 3693 & 21.00 & 102 & 2230 & 4839 & 255 & 106,310 & 5739 \\
\hline 2010 & 308 & 3468 & 22.19 & 85 & 2310 & 3826 & 160 & 104,261 & 4605 \\
\hline 2011 & 259 & 3331 & 16.18 & 51 & 1570 & 3142 & 145 & 96,935 & 4844 \\
\hline
\end{tabular}

Panel C: Stock Characteristics

\begin{tabular}{|c|c|c|c|c|c|}
\hline & $\begin{array}{l}\text { Turnover } \\
(\%)\end{array}$ & $\begin{array}{c}\text { Market Capitalization } \\
\text { (\$billions) }\end{array}$ & $\begin{array}{l}\text { Amihud Illiquidity } \\
\text { (in millions) }\end{array}$ & $\begin{array}{l}\text { No. Shares Traded } \\
\text { (millions) }\end{array}$ & $\begin{array}{l}\text { Return } \\
\quad(\%)\end{array}$ \\
\hline \multicolumn{6}{|c|}{ Firm Size (quantile) } \\
\hline Small & 211 & 0.37 & 0.0182 & 2.15 & 2 \\
\hline 2 & 255 & 0.80 & 0.0043 & 3.60 & 3 \\
\hline 3 & 275 & 1.54 & 0.0019 & 5.90 & 4 \\
\hline 4 & 269 & 3.45 & 0.0008 & 10.40 & 3 \\
\hline Large & 218 & 28.00 & 0.0002 & 33.70 & 3 \\
\hline Full Sample & 245.6 & 6.83 & 0.0051 & 11.15 & 3 \\
\hline
\end{tabular}




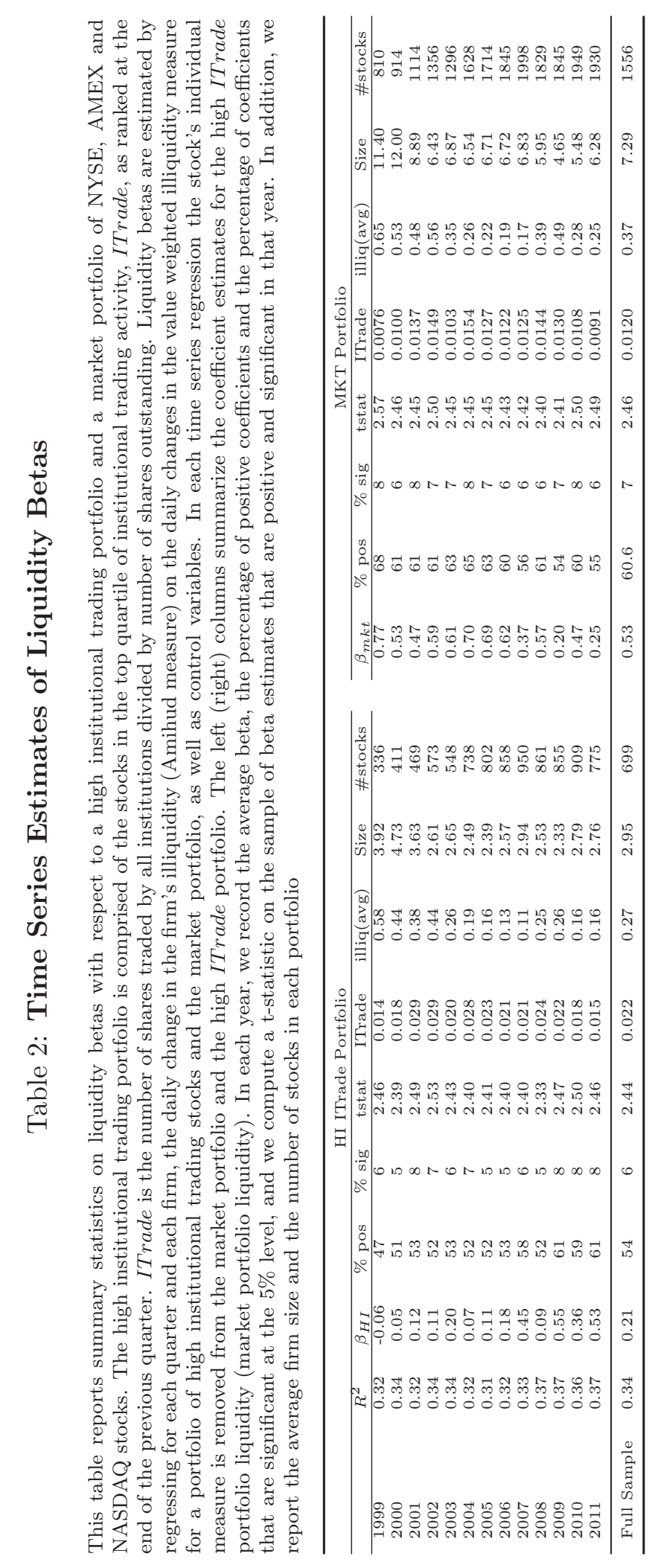




\section{Table 3: Relationship between Commonality in Liquidity and Institutional Trades}

This table reports results from pooled OLS regressions of estimates of on selected stock characteristics measured at the end of the previous quarter. $\beta_{H I}$ is estimated from time-series regressions of daily changes in liquidity on changes in liquidity of a portfolio of stocks highly traded by institutions. ITrade is the number of shares traded by institutions divided by number of shares outstanding, MTrade is the total volume for as reported in CRSP, divided by the number of shares outstanding. illiq $(a v g)$ is the firm's average Amihud (2002) illiquidity measure over the previous quarter. $m$ fown is the number of shares held by all equity mutual funds divided by number of shares outstanding. $\ln ($ size) is the natural logarithm of market capitalization. Panel A uses the standard measure of ITrade and Panel B uses a dummy equal to 1 if ITrade is in the top quartile in a given quarter, and zero otherwise. Quarter dummies are included in columns (1) to (3). Standard errors are clustered by firm in columns (1) to (4). Column (3) contains firm fixed effects. In column (4) standard errors are clustered by quarters. Column (5) reports results from Fama-MacBeth (1973) regressions.

\begin{tabular}{|c|c|c|c|c|c|c|}
\hline Panel A & (1) & (2) & (3) & (4) & (5) & (6) \\
\hline ITrade & $\begin{array}{c}54.66^{* * *} \\
(5.98)\end{array}$ & $\begin{array}{c}60.75^{* * *} \\
(6.39)\end{array}$ & $\begin{array}{c}32.25^{* * *} \\
(4.26)\end{array}$ & $\begin{array}{c}45.06^{* * *} \\
(4.38)\end{array}$ & $\begin{array}{c}68.56^{* * *} \\
(6.61)\end{array}$ & $\begin{array}{c}107.5^{* * *} \\
(8.29)\end{array}$ \\
\hline mfown & & & & & & $\begin{array}{c}0.480^{* * * *} \\
(4.39)\end{array}$ \\
\hline MTrade & $\begin{array}{c}29.15^{* * *} \\
(20.44)\end{array}$ & $\begin{array}{c}28.08^{* * *} \\
(19.27)\end{array}$ & $\begin{array}{c}16.89 * * * \\
(11.26)\end{array}$ & $\begin{array}{c}30.03^{* * *} \\
(12.81)\end{array}$ & $\begin{array}{c}25.36^{* * *} \\
(13.66)\end{array}$ & $\begin{array}{c}26.26^{* * *} \\
(14.71)\end{array}$ \\
\hline illiq(avg) & & $\begin{array}{l}-285^{* *} \\
(-2.23)\end{array}$ & $\begin{array}{l}-129^{*} \\
(-1.67)\end{array}$ & $\begin{array}{l}-206^{*} \\
(-1.75)\end{array}$ & $\begin{array}{c}422 \\
(0.22)\end{array}$ & $\begin{array}{c}-470^{* * *} \\
(-5.20)\end{array}$ \\
\hline $\ln ($ size $)$ & & $\begin{array}{c}0.05^{* * *} \\
(6.41)\end{array}$ & $\begin{array}{c}0.09^{* * *} \\
(4.39)\end{array}$ & $\begin{array}{l}0.05^{* *} \\
(2.06)\end{array}$ & $\begin{array}{l}0.04^{*} \\
(1.87)\end{array}$ & $\begin{array}{c}0.0615^{* * *} \\
(7.16)\end{array}$ \\
\hline Observations & 74875 & 74875 & 74875 & 74875 & 74875 & 60043 \\
\hline$R^{2}$ & 0.035 & 0.04 & 0.03 & 0.02 & 0.02 & 0.04 \\
\hline \multicolumn{7}{|l|}{ Panel B } \\
\hline$D_{\text {ITrade }}$ & $\begin{array}{c}0.1494^{* * *} \\
(7.16)\end{array}$ & $\begin{array}{c}0.1730^{* * * *} \\
(8.32)\end{array}$ & $\begin{array}{c}0.0640^{* * * *} \\
(2.92)\end{array}$ & $\begin{array}{c}0.1601^{* * *} \\
(5.51)\end{array}$ & $\begin{array}{c}0.1476^{* * * *} \\
(6.52)\end{array}$ & $\begin{array}{c}0.154^{* * *} \\
(6.44)\end{array}$ \\
\hline mfown & & & & & & $\begin{array}{c}0.514^{* * *} \\
(4.68)\end{array}$ \\
\hline MTrade & $\begin{array}{c}29.42^{* * *} \\
(20.83)\end{array}$ & $\begin{array}{c}28.22^{* * *} \\
(19.65)\end{array}$ & $\begin{array}{c}17.43^{* * *} \\
(11.45)\end{array}$ & $\begin{array}{c}9.60 * * * \\
(11.86)\end{array}$ & $\begin{array}{c}26.03 \\
(13.92)\end{array}$ & $\begin{array}{c}28.99^{* * *} * \\
(16.54)\end{array}$ \\
\hline illiq(avg) & & $\begin{array}{l}-288^{* *} \\
(-2.25)\end{array}$ & $\begin{array}{c}133^{*} \\
(-1.72)\end{array}$ & $\begin{array}{l}-201^{*} \\
(-1.72)\end{array}$ & $\begin{array}{c}38 \\
(0.19)\end{array}$ & $\begin{array}{c}-505^{* * *} \\
(-5.44)\end{array}$ \\
\hline $\ln ($ size $)$ & & $\begin{array}{c}0.06^{* * *} \\
(6.45)\end{array}$ & $\begin{array}{c}0.09^{* * *} \\
(4.52)\end{array}$ & $\begin{array}{l}0.05^{* *} \\
(2.10)\end{array}$ & $\begin{array}{l}0.04^{*} \\
(1.86)\end{array}$ & $\begin{array}{c}0.0578^{* * *} \\
(6.70)\end{array}$ \\
\hline Observations & 74875 & 74875 & 74875 & 74875 & 74875 & 60043 \\
\hline$R^{2}$ & 0.04 & 0.04 & 0.03 & 0.02 & 0.02 & 0.04 \\
\hline Time effects & $\mathrm{Y}$ & Y & Y & & & Y \\
\hline Firm effects & & & Y & & & \\
\hline Time cluster & & & & $\mathrm{Y}$ & & \\
\hline Firm cluster & Y & Y & $\mathrm{Y}$ & Y & & $\mathrm{Y}$ \\
\hline Fama MacBeth & & & & & Y & \\
\hline
\end{tabular}




\section{Table 4: Relationship between Commonality in Liquidity and Institutional Trades: Sub-sample Analysis}

This table reports results from pooled OLS regressions of estimates of on selected stock characteristics measured at the end of the previous quarter for different subsamples. $\beta_{H I}$ is estimated from time-series regressions of daily changes in liquidity on changes in liquidity of a portfolio of stocks highly traded by institutions. ITrade is the number of shares traded by institutions divided by number of shares outstanding, MTrade is the total volume for as reported in CRSP, divided by the number of shares outstanding. illiq $(\mathrm{avg})$ is the firm's average Amihud (2002) illiquidity measure over the previous quarter. $m$ fown is the number of shares held by all equity mutual funds divided by number of shares outstanding. $\ln (\operatorname{size})$ is the natural logarithm of market capitalization. Panels $\mathrm{A}$ and $\mathrm{C}$ report results of regressions for size and illiquidity quartile-based subsamples. Panels B and D report results of regressions for two subperiods and for up- and down-markets separately, where up (down) market periods are quarters in which the market return was positive (negative). Panels A and B use the standard measure of ITrade, and Panels C and D use a dummy equal to 1 if ITrade is in the top quartile in a given quarter, and zero otherwise. Quarter dummies are included in all regressions. Standard errors are clustered by firm.

\begin{tabular}{|c|c|c|c|c|c|c|c|c|}
\hline & & & Size & & & Illiq(avg) & & \\
\hline Panel A & Low & 2 & 3 & High & Low & 2 & 3 & High \\
\hline ITrade & $\begin{array}{c}83.22 * * * \\
(3.88)\end{array}$ & $\begin{array}{c}97.17^{* * *} \\
(4.49)\end{array}$ & $\begin{array}{c}95.75^{* * * *} \\
(3.44)\end{array}$ & $\begin{array}{c}85.40^{* * *} \\
(3.01)\end{array}$ & $\begin{array}{c}76.36^{* * *} * \\
(3.17)\end{array}$ & $\begin{array}{c}93.81 * * * \\
(3.67)\end{array}$ & $\begin{array}{c}108.3^{* * *} * \\
(4.98)\end{array}$ & $\begin{array}{c}40.2 \\
(1.53)\end{array}$ \\
\hline mfown & $\begin{array}{l}0.286 \\
(1.26)\end{array}$ & $\begin{array}{l}0.160 \\
(0.98)\end{array}$ & $\begin{array}{c}0.575^{* *} \\
(2.55)\end{array}$ & $\begin{array}{c}0.584^{* *} \\
(2.01)\end{array}$ & $\begin{array}{l}0.554^{*} \\
(1.96)\end{array}$ & $\begin{array}{c}0.504 * * \\
(2.18)\end{array}$ & $\begin{array}{c}-0.0249 \\
(-0.15)\end{array}$ & $\begin{array}{l}0.338 \\
(1.57)\end{array}$ \\
\hline MTrade & $\begin{array}{c}30.29 * * * \\
(9.08)\end{array}$ & $\begin{array}{c}25.92^{* * * *} \\
(9.64)\end{array}$ & $\begin{array}{c}18.46^{* * * *} \\
(6.90)\end{array}$ & $\begin{array}{c}24.76^{* * * *} \\
(5.82)\end{array}$ & $\begin{array}{c}23.36^{* * * *} \\
(7.47)\end{array}$ & $\begin{array}{c}22.32^{* * * *} \\
(7.20)\end{array}$ & $\begin{array}{c}34.54^{* * * *} \\
(8.98)\end{array}$ & $\begin{array}{c}52.22 * * * \\
(8.83)\end{array}$ \\
\hline illiq(avg) & $\begin{array}{c}-266 * * * \\
(-2.73)\end{array}$ & $\begin{array}{c}-351 \\
(-1.02)\end{array}$ & $\begin{array}{c}52 \\
(0.05)\end{array}$ & $\begin{array}{c}10520^{* *} \\
(2.58)\end{array}$ & $\begin{array}{c}37141 * * * \\
(2.73)\end{array}$ & $\begin{array}{c}8443^{* * *} \\
(3.11)\end{array}$ & $\begin{array}{c}1184^{* *} \\
(2.31)\end{array}$ & $\begin{array}{c}-104 \\
(-1.13)\end{array}$ \\
\hline $\ln ($ size $)$ & $\begin{array}{l}0.0163 \\
(0.29)\end{array}$ & $\begin{array}{c}0.0849 \\
(1.29)\end{array}$ & $\begin{array}{c}0.143^{* *} \\
(2.41)\end{array}$ & $\begin{array}{l}0.0251 \\
(1.05)\end{array}$ & $\begin{array}{l}0.0809^{* * * *} \\
(2.62)\end{array}$ & $\begin{array}{c}0.263^{* * * *} \\
(4.84)\end{array}$ & $\begin{array}{c}0.108^{* *} \\
(2.18)\end{array}$ & $\begin{array}{l}0.0392 \\
(0.82)\end{array}$ \\
\hline Observations & 14283 & 14976 & 15259 & 15525 & 15555 & 15345 & 15052 & 14091 \\
\hline$R^{2}$ & 0.04 & 0.04 & 0.05 & 0.08 & 0.08 & 0.05 & 0.04 & 0.03 \\
\hline Panel B & 1999-2003 & & 2004-2007 & & 2008-2011 & & Down Mkt & Up Mkt \\
\hline ITrade & $\begin{array}{c}147.8^{* * * *} \\
(4.01)\end{array}$ & & $\begin{array}{c}76.86^{* * * *} \\
(4.12)\end{array}$ & & $\begin{array}{c}107.0^{* * *} \\
(4.12)\end{array}$ & & $\begin{array}{c}98.35^{* * *} \\
(6.70)\end{array}$ & $\begin{array}{c}130.6^{* * *} \\
(5.95)\end{array}$ \\
\hline mfown & $\begin{array}{l}3.069 \\
(1.04)\end{array}$ & & $\begin{array}{c}6.413 * * * \\
(3.78)\end{array}$ & & $\begin{array}{c}0.436^{* * *} \\
(4.05)\end{array}$ & & $\begin{array}{c}0.444^{* * *} * \\
(4.09)\end{array}$ & $\begin{array}{c}4.372 * * * \\
(3.84)\end{array}$ \\
\hline MTrade & $\begin{array}{c}32.03^{* * *} \\
(6.85)\end{array}$ & & $\begin{array}{c}25.33^{* * * *} \\
(9.76)\end{array}$ & & $\begin{array}{c}22.52^{* * *} * \\
(9.59)\end{array}$ & & $\begin{array}{c}26.40^{* * * *} \\
(13.56)\end{array}$ & $\begin{array}{c}24.71^{* * *} \\
(10.29)\end{array}$ \\
\hline illiq(avg) & $\begin{array}{l}585^{* *} \\
(2.02)\end{array}$ & & $\begin{array}{c}273 \\
(0.85)\end{array}$ & & $\begin{array}{c}-454 * * * \\
(-4.49)\end{array}$ & & $\begin{array}{c}-617 * * * \\
(-4.88)\end{array}$ & $\begin{array}{c}-392 * * * \\
(-3.73)\end{array}$ \\
\hline $\ln ($ size $)$ & $\begin{array}{c}-0.0917^{* * *} \\
(-3.83)\end{array}$ & & $\begin{array}{c}-0.00193 \\
(-0.14)\end{array}$ & & $\begin{array}{c}0.177^{* * * *} \\
(15.91)\end{array}$ & & $\begin{array}{l}0.0591 * * * \\
(6.09)\end{array}$ & $\begin{array}{c}0.0553^{* * * *} \\
\quad(4.28)\end{array}$ \\
\hline \multirow{3}{*}{$\begin{array}{l}\text { Observations } \\
R^{2}\end{array}$} & 6878 & & 26033 & & 27132 & & 44636 & 15464 \\
\hline & 0.04 & & 0.02 & & 0.07 & & 0.04 & 0.06 \\
\hline & & Size & & & & & Illiq(avg) & \\
\hline Panel C & Low & 2 & 3 & High & Low & 2 & 3 & High \\
\hline$D_{\text {ITrade }}$ & $\begin{array}{c}0.116^{* *} \\
(2.36)\end{array}$ & $\begin{array}{c}0.145^{* * *} \\
(3.35)\end{array}$ & $\begin{array}{c}0.201^{* * * *} \\
(4.48)\end{array}$ & $\begin{array}{c}0.00861 \\
(0.17)\end{array}$ & $\begin{array}{l}0.0462 \\
(0.98)\end{array}$ & $\begin{array}{c}0.202^{* * *} * \\
(4.75)\end{array}$ & $\begin{array}{c}0.149^{* * * *} \\
(3.36)\end{array}$ & $\begin{array}{c}0.00977 \\
(0.17)\end{array}$ \\
\hline mfown & $\begin{array}{l}0.319 \\
(1.41)\end{array}$ & $\begin{array}{l}0.189 \\
(1.16)\end{array}$ & $\begin{array}{c}0.565^{* *} \\
(2.52)\end{array}$ & $\begin{array}{c}0.663^{* *} \\
(2.24)\end{array}$ & $\begin{array}{c}0.608^{* *} \\
(2.13)\end{array}$ & $\begin{array}{c}0.499^{* *} \\
(2.15)\end{array}$ & $\begin{array}{r}0.0137 \\
(0.08)\end{array}$ & $\begin{array}{c}0.359^{*} \\
(1.67)\end{array}$ \\
\hline MTrade & $\begin{array}{c}32.79 * * * \\
(9.92)\end{array}$ & $\begin{array}{c}28.33^{* * *} * \\
(10.62)\end{array}$ & $\begin{array}{c}19.39^{* * *} \\
(7.97)\end{array}$ & $\begin{array}{c}28.39^{* * *} * \\
(6.63)\end{array}$ & $\begin{array}{c}25.52^{* * *} * \\
(8.25)\end{array}$ & $\begin{array}{c}23.18^{* * *} \\
(7.80)\end{array}$ & $\begin{array}{c}37.86^{* * * *} \\
(9.97)\end{array}$ & $\begin{array}{c}55.47^{* * *} \\
(9.50)\end{array}$ \\
\hline illiq(avg) & $\begin{array}{c}-288^{* * *} * \\
(-2.91)\end{array}$ & $\begin{array}{c}-457 \\
(-1.31)\end{array}$ & $\begin{array}{c}-225 \\
(-0.22)\end{array}$ & $\begin{array}{c}9444^{* *} \\
(2.42)\end{array}$ & $\begin{array}{c}35516^{* * *} \\
(2.60)\end{array}$ & $\begin{array}{c}8508^{* * *} * \\
(3.10)\end{array}$ & $\begin{array}{c}1103^{* *} \\
(2.16)\end{array}$ & $\begin{array}{c}-110 \\
(-1.19)\end{array}$ \\
\hline $\ln ($ size $)$ & $\begin{array}{l}0.0068 \\
(0.12)\end{array}$ & $\begin{array}{l}0.0753 \\
(1.15)\end{array}$ & $\begin{array}{c}0.0944^{*} \\
(1.90)\end{array}$ & $\begin{array}{l}0.0136 \\
(0.62)\end{array}$ & $\begin{array}{c}0.0693^{* *} \\
(2.22)\end{array}$ & $\begin{array}{c}0.261^{* * *} * \\
(4.80)\end{array}$ & $\begin{array}{c}0.0946^{*} \\
(1.89)\end{array}$ & $\begin{array}{l}0.0313 \\
(0.66)\end{array}$ \\
\hline Observations & 14283 & 14976 & 15259 & 15525 & 15555 & 15345 & 15052 & 14091 \\
\hline$R^{2}$ & 0.04 & 0.04 & 0.05 & 0.08 & 0.08 & 0.05 & 0.04 & 0.03 \\
\hline Panel D & 1999-2003 & & $2004-2007$ & & 2008-2011 & & Down Mkt & Up Mkt \\
\hline$D_{\text {ITrade }}$ & $\begin{array}{c}0.146 * * \\
(2.02)\end{array}$ & & $\begin{array}{c}0.133 * * * \\
(3.57)\end{array}$ & & $\begin{array}{c}0.137 * * * \\
(4.19)\end{array}$ & & $\begin{array}{c}0.149^{* * *} \\
(5.34)\end{array}$ & $\begin{array}{c}0.152^{* * * *} \\
(3.67)\end{array}$ \\
\hline mfown & $\begin{array}{l}4.418 \\
(1.47)\end{array}$ & & $\begin{array}{c}7.171^{* * * *} \\
(4.29)\end{array}$ & & $\begin{array}{c}0.470 * * * \\
(4.35)\end{array}$ & & $\begin{array}{c}0.468^{* * * *} \\
(4.30)\end{array}$ & $\begin{array}{c}4.902^{* * *} \\
(4.28)\end{array}$ \\
\hline MTrade & $\begin{array}{c}35.59^{* * * *} \\
(7.41)\end{array}$ & & $\begin{array}{c}26.99 * * * \\
(10.89)\end{array}$ & & $\begin{array}{c}25.34^{* * *} \\
(11.10)\end{array}$ & & $\begin{array}{c}28.80 * * * \\
(15.23)\end{array}$ & $\begin{array}{c}28.29 * * * \\
(11.94)\end{array}$ \\
\hline illiq(avg) & $\begin{array}{l}571^{* *} \\
(1.99)\end{array}$ & & $\begin{array}{c}254 \\
(0.79)\end{array}$ & & $\begin{array}{c}-493^{* * *} \\
(-4.73)\end{array}$ & & $\begin{array}{c}-656^{* * *} \\
(-5.14)\end{array}$ & $\begin{array}{c}-432 * * * \\
(-4.00)\end{array}$ \\
\hline $\ln ($ size $)$ & $\begin{array}{c}-0.101^{* * * *} \\
(-4.21)\end{array}$ & & $\begin{array}{c}-0.00426 \\
(-0.32)\end{array}$ & & $\begin{array}{c}0.174^{* * *} \\
(15.58)\end{array}$ & & $\begin{array}{c}0.0557^{* * *} \\
(5.73)\end{array}$ & $\begin{array}{c}0.0497^{* * * *} \\
(3.83)\end{array}$ \\
\hline Observations & 6878 & & 26033 & & 27132 & & 44636 & 15464 \\
\hline$R^{2}$ & 0.05 & & 0.02 & & 0.07 & & 0.04 & 0.06 \\
\hline
\end{tabular}




\section{Table 5: Relation Between Liquidity Commonality and Institutional Trades Conditional on Aggregate Mutual Fund Flows}

This table reports results from pooled OLS regressions of estimates of on selected stock characteristics measured at the end of the previous quarter, conditional on aggregate mutual fund flows. $\beta_{H I}$ is estimated from time-series regressions of daily changes in liquidity on changes in liquidity of a portfolio of stocks highly traded by institutions. ITrade is the number of shares traded by institutions divided by number of shares outstanding, MTrade is the total volume for as reported in CRSP, divided by the number of shares outstanding. illiq(avg) is the firm's average Amihud (2002) illiquidity measure over the previous quarter. $m$ fown is the number of shares held by all equity mutual funds divided by number of shares outstanding. $\ln ($ size) is the natural logarithm of market capitalization. In columns (1) to (4) we interact ITrade and MTrade with dummies based on aggregate net flows. All aggregate flows are scaled by total US market capitalization and flows are measured contemporaneously with $\beta_{H I}$. In columns (1) and (2) we interact ITrade with a dummy variable extremflow that equals one if aggregate net flows are in either the highest $10 \%$ or lowest $10 \%$ for that quarter, and zero otherwise. In column (2) and(4) we interact ITrade and MTrade with a dummy variable negflow that equals one if aggregate net flows are negative for that quarter, and zero otherwise. In column (5) and (6) we control for $m f$ own. Quarter dummies are included but not reported. Standard errors are clustered by firm.

\begin{tabular}{|c|c|c|c|c|c|c|}
\hline & $(1)$ & $(2)$ & (3) & (4) & (5) & (6) \\
\hline ITrade & $\begin{array}{c}54.15^{* * *} \\
(5.49)\end{array}$ & $\begin{array}{c}56.23^{* * *} \\
(5.59)\end{array}$ & $\begin{array}{c}58.45^{* * *} \\
(5.17)\end{array}$ & $\begin{array}{c}58.44^{* * *} \\
(4.98)\end{array}$ & $\begin{array}{c}106.3^{* * *} \\
(7.57)\end{array}$ & $\begin{array}{c}106.0^{* * *} \\
(5.70)\end{array}$ \\
\hline ITrade*extremflow & $\begin{array}{c}40.27^{* * * *} \\
(2.72)\end{array}$ & $\begin{array}{l}29.49^{*} \\
(1.77)\end{array}$ & & & $\begin{array}{l}9.113 \\
(0.36)\end{array}$ & \\
\hline ITrade*negflow & & & $\begin{array}{l}6.046 \\
(0.45)\end{array}$ & $\begin{array}{l}6.065 \\
(0.40)\end{array}$ & & $\begin{array}{l}1.897 \\
(0.08)\end{array}$ \\
\hline mfown & & & & & $\begin{array}{c}0.387 * * * \\
(3.00)\end{array}$ & $\begin{array}{c}0.16 \\
(0.77)\end{array}$ \\
\hline mfown*extremflow & & & & & $\begin{array}{c}0.273 \\
(1.44)\end{array}$ & \\
\hline mfown*negflow & & & & & & $\begin{array}{c}0.470 * * \\
(2.07)\end{array}$ \\
\hline MTrade & $\begin{array}{c}27.98^{* * * *} \\
(19.26)\end{array}$ & $\begin{array}{c}27.20^{* * * *} \\
(18.42)\end{array}$ & $\begin{array}{c}28.05^{* * *} \\
(19.35)\end{array}$ & $\begin{array}{c}28.05^{* * *} \\
(16.98)\end{array}$ & $\begin{array}{c}25.61 * * * \\
(13.60)\end{array}$ & $\begin{array}{c}27.93^{* * *} \\
(11.74)\end{array}$ \\
\hline MTrade*extremflow & & $\begin{array}{l}3.371 \\
(1.39)\end{array}$ & & & $\begin{array}{l}2.332 \\
(0.87)\end{array}$ & \\
\hline MTrade*negflow & & & & $\begin{array}{c}-0.00663 \\
(-0.00)\end{array}$ & & $\begin{array}{l}-2.746 \\
(-1.13)\end{array}$ \\
\hline illiq(avg) & $\begin{array}{l}-284^{* *} \\
(-2.23)\end{array}$ & $\begin{array}{l}-285^{* *} \\
(-2.23)\end{array}$ & $\begin{array}{l}-284^{* *} \\
(-2.23)\end{array}$ & $\begin{array}{l}-284 * * \\
(-2.23)\end{array}$ & $\begin{array}{c}-471 * * * \\
(-5.21)\end{array}$ & $\begin{array}{c}-469 * * * \\
(-5.18)\end{array}$ \\
\hline $\ln ($ size $)$ & $\begin{array}{l}0.0550^{* * * *} \\
\quad(6.42)\end{array}$ & $\begin{array}{l}0.0549^{* * *} \\
\quad(6.40)\end{array}$ & $\begin{array}{l}0.0549^{* * * *} \\
\quad(6.41)\end{array}$ & $\begin{array}{l}0.0549^{* * * *} \\
\quad(6.42)\end{array}$ & $\begin{array}{l}0.0616^{* * *} \\
\quad(7.16)\end{array}$ & $\begin{array}{c}0.0619^{* * * *} \\
\quad(7.20)\end{array}$ \\
\hline Observations & 74875 & 74875 & 74875 & 74875 & 60043 & 60043 \\
\hline$R^{2}$ & 0.038 & 0.038 & 0.038 & 0.038 & 0.041 & 0.041 \\
\hline
\end{tabular}


Table 6: Number of Stocks, Pairs and Institutions Per Year

This table lists the total number of stocks, pairs of stocks, and institutions for every year of the sample period. The sample consists of all NYSE-AMEX-NASDAQ stocks that are above NYSE median capitalization as of the end of each month. The fourth column lists the number of institutions that trade at least one of the stocks in the sample.

\begin{tabular}{cccc}
\hline Year & Stocks & Pairs & Institutions \\
\hline 1999 & 737 & 271216 & 379 \\
2000 & 839 & 351541 & 370 \\
2001 & 837 & 349866 & 398 \\
2002 & 813 & 330078 & 424 \\
2003 & 817 & 333336 & 401 \\
2004 & 988 & 487578 & 404 \\
2005 & 1081 & 583740 & 376 \\
2006 & 1170 & 683865 & 399 \\
2007 & 1185 & 701520 & 377 \\
2008 & 1027 & 526851 & 333 \\
2009 & 845 & 356590 & 322 \\
2010 & 1003 & 502503 & 308 \\
2011 & 1070 & 571915 & 259 \\
\hline
\end{tabular}




\section{Table 7: Number of Institutions and Stocks Summary Statistics}

This table reports summary statistics for the sample defined in Table 6 over the following variables: number of institutions that trade each stock and number of stocks traded by each institution.

Panel A: 1999-2011

\begin{tabular}{lccccc}
\hline \hline & Mean & Median & SD & Min & Max \\
\hline Institutions per stock & 129.74 & 121 & 61.79 & 1 & 361 \\
Stocks per Institution & 612.76 & 566 & 341.90 & 1 & 1508 \\
\hline
\end{tabular}

Panel B: 1999-2002

\begin{tabular}{lccccc}
\hline \hline & Mean & Median & SD & Min & Max \\
\hline Institutions per stock & 142.84 & 130 & 74.35 & 1 & 361 \\
Stocks per Institution & 509.30 & 454 & 296.55 & 1 & 1468 \\
\hline
\end{tabular}

Panel C: 2003-2007

\begin{tabular}{lccccc}
\hline \hline & Mean & Median & SD & Min & Max \\
\hline Institutions per stock & 123.89 & 116 & 56.69 & 1 & 348 \\
Stocks per Institution & 652.83 & 599 & 361.25 & 1 & 1508 \\
\hline
\end{tabular}

Panel D: 2008-2011

\begin{tabular}{lccccc}
\hline \hline & Mean & Median & SD & Min & Max \\
\hline Institutions per stock & 124.32 & 119 & 51.60 & 1 & 276 \\
Stocks per Institution & 663.41 & 641 & 335.75 & 1 & 1324 \\
\hline
\end{tabular}




\section{Table 8: The Cross-sectional Distribution of Common Institutions}

This table reports the distribution of the variable $F_{i j, t}$ measuring the number of Institutions trading both stocks in a pair during the previous month. The distribution is shown for the average of full sample and for each year in the sample.

\begin{tabular}{lcccccccccc}
\hline \hline & \multicolumn{1}{l}{ Common Institutions $\left(F_{i j . t}\right)$} & & \multicolumn{3}{c}{ Percentiles } \\
\hline & mean & sd & $0 \%$ & $25 \%$ & $50 \%$ & $75 \%$ & $90 \%$ & $95 \%$ & $99 \%$ & $100 \%$ \\
\hline Full Sample & 15.93 & 10.77 & 1 & 9 & 14 & 21 & 29 & 36 & 53 & 185 \\
\hline 1999 & 8.34 & 7.12 & 1 & 4 & 6 & 11 & 16 & 21 & 36 & 132 \\
2000 & 10.59 & 8.86 & 1 & 5 & 8 & 13 & 21 & 27 & 44 & 158 \\
2001 & 14.00 & 10.58 & 1 & 7 & 11 & 18 & 26 & 33 & 54 & 170 \\
2002 & 17.27 & 12.05 & 1 & 9 & 15 & 22 & 32 & 40 & 61 & 185 \\
2003 & 15.62 & 11.01 & 1 & 8 & 13 & 21 & 30 & 36 & 53 & 167 \\
2004 & 15.18 & 9.30 & 1 & 9 & 13 & 19 & 27 & 33 & 47 & 170 \\
2005 & 13.45 & 8.52 & 1 & 8 & 12 & 17 & 24 & 30 & 43 & 117 \\
2006 & 14.60 & 9.54 & 1 & 8 & 13 & 18 & 26 & 33 & 49 & 124 \\
2007 & 15.66 & 9.29 & 1 & 9 & 14 & 20 & 27 & 33 & 48 & 131 \\
2008 & 20.20 & 11.28 & 1 & 13 & 18 & 25 & 34 & 41 & 58 & 164 \\
2009 & 26.00 & 12.81 & 1 & 17 & 24 & 32 & 42 & 50 & 68 & 161 \\
2010 & 20.98 & 10.86 & 1 & 14 & 19 & 26 & 35 & 42 & 58 & 140 \\
2011 & 16.28 & 9.05 & 1 & 10 & 14 & 20 & 28 & 34 & 48 & 118 \\
\hline
\end{tabular}




\section{Table 9: Liquidity Commonality in a Pair of Stocks}

This table reports Fama-McBeth estimate of monthly cross-sectional regressions forecasting the realized cross-product of changes in stock illiquidity for a sample of stocks. The predictive variables are updated monthly and include our main measure of institutional connectedness, the number of institutions trading in both stocks $F_{i j, t}$, and a series of controls at time $t$. We measure the negative of the absolute value of the difference in size, BE/ME and momentum percentile ranking across the two stocks in the pair (DIFF_SIZE $E_{i j, t}, D I F F_{-} B E M E_{i j, t}, D I F F_{-} M O M_{i j, t}$ respectively). We also measure the number of similar SIC digits, $N U M_{-} S I C_{i j, t}$ for the two stocks in a pair as well as size percentile of each stock in the pair and an interaction $\left(S I Z E 1_{i j, t}, S I Z E 2_{i j, t}, S I Z E 1 S I Z E 2_{i j, t}\right)$. All independent variables are then rank transformed and normalized to have a unit standard deviation, which we denote with an asterisk superscript. We calculate Newey-West standard errors (four lags) of the Fama-MacBeth estimates that take into account autocorrelation in the cross-sectional slopes.

\begin{tabular}{lcccc}
\hline & $(1)$ & $(2)$ & $(3)$ & $(4)$ \\
\hline$F^{*}$ & 0.012291 & 0.011933 & 0.0115026 & 0.011701 \\
& $(5.76)$ & $(5.5)$ & $(7.72)$ & $(7.99)$ \\
Constant & 0.160091 & 0.1601237 & 0.1602023 & 0.160197 \\
& $(7.46)$ & $(7.46)$ & $(7.47)$ & $(7.47)$ \\
& & & & 0.003348 \\
DIFF_SIZE* & & 0.0036667 & & $(7.15)$ \\
& $(7.22)$ & & 0.00443 \\
DIFF_BEME* & & 0.004423 & & $(6.54)$ \\
& & $(6.29)$ & & 0.008832 \\
DIFF_MOM* & & 0.0088546 & & $(6.05)$ \\
& & $(6.01)$ & & 0.017803 \\
NUM_SIC* & & 0.017847 & & $(16.74)$ \\
& & $(16.84)$ & & $(0.17)$ \\
SIZE1* & & 0.0008424 & 0.000299 \\
SIZE2* & & $(0.46)$ & -0.00051 \\
& & & $(-0.0000245$ & $(-0.3)$ \\
SIZE1SIZE2* & & & 0.0050063 & 0.004559 \\
& & & $(12.51)$ & $(12.5)$ \\
\hline
\end{tabular}




\section{Table 10: Mutual fund Scandal of 2003}

This table reports results from a 2SLS instrumental variables regression based on mutual funds scandal 2003 . In the first stage we predict the variable ITrade $i t$ with the the fraction of shares owned by all scandal funds divided by the fraction

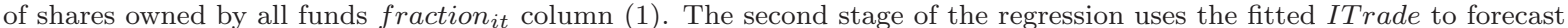
the $\beta_{H I, i t+1}$ column (2). In column (3) we use the variable $\Delta$ fraction as an instrument to predict $\Delta I T r a d e$. Where

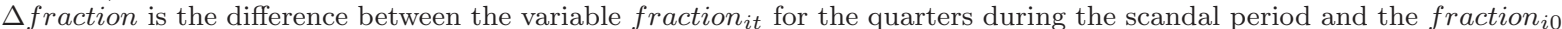
one quarter before the scandal broke, and $\Delta I$ Trade is defined in the same way. Column (4) reports the second stage results where we use $\Delta \beta_{H I}$ as dependent variable. Time dummies are included but not reported

\begin{tabular}{lcc}
\hline & $(1)$ & $(2)$ \\
ITrade & & 1325.6 \\
& & $(2.19)$ \\
mfown & $4.09 \mathrm{E}-12$ & $5.28 \mathrm{E}-09$ \\
& $(3.16)$ & $(1.15)$ \\
fraction & 0.0001464 & \\
& $(4.63)$ & \\
MTrade & 0.0638 & -53.23784 \\
& $(67.38)$ & $(-1.37)$ \\
ln(size) & -0.0000909 & 0.0576 \\
& $(-13.98)$ & $(0.91)$ \\
Time effects & Yes & Yes \\
Observation & 13962 & 13962 \\
$R^{2}$ & 0.32 & \\
F-stat & 21.46 & \\
\hline
\end{tabular}




\section{Table 11: Robustness Tests: Controlling for Return and Volatility Comovement}

This table reports results from pooled OLS regressions of estimates of on selected stock characteristics measured at the end of the previous quarter, conditional on aggregate mutual fund flows. $\beta_{H I}$ is estimated from time-series regressions of daily changes in liquidity on changes in liquidity of a portfolio of stocks highly traded by institutions. ITrade is the number of shares traded by institutions divided by number of shares outstanding, MTrade is the total volume for as reported in CRSP, divided by the number of shares outstanding. illiq(avg) is the firm's average Amihud (2002) illiquidity measure over the previous quarter. mfown is the number of shares held by all equity mutual funds divided by number of shares outstanding. $\ln ($ size $)$ is the natural logarithm of market capitalization. The first column repeats the standard regression of $\beta_{H I}$ on ITrade and includes as an additional control variable the beta estimate between the firm return and the value-weighted return on the high institutional trading portfolio estimated contemporaneously with the liquidity beta. columns (2) to (5) run the above regression on cross-sectional sub-samples sorted by the return beta. Model (6) runs the same regression, but controls for return covariation in the first stage. Specifically, the dependent variable is a liquidity beta estimated in a time series regression that controls for firm returns and the return on the high institutional trading portfolio. We repeat this analysis in Panel B, substituting squared returns, return ${ }^{2}$, for returns, as a proxy for volatility.

\begin{tabular}{|c|c|c|c|c|c|c|}
\hline \multicolumn{7}{|c|}{ Panel A: Controlling for Comovement in Return } \\
\hline & & \multicolumn{4}{|c|}{ Return Beta } & \\
\hline & & Low & 2 & 3 & High & \\
\hline & (1) & $(2)$ & (3) & (4) & $(5)$ & $(6)$ \\
\hline ITrade & $\begin{array}{c}110.0^{* * *} \\
(8.85)\end{array}$ & $\begin{array}{c}111.7^{* * * *} \\
(3.59)\end{array}$ & $\begin{array}{c}84.20^{* * *} \\
(3.46)\end{array}$ & $\begin{array}{c}118.1^{* * *} \\
(5.39)\end{array}$ & $\begin{array}{c}98.21^{* * *} \\
(5.00)\end{array}$ & $\begin{array}{c}108.9^{* * * *} \\
(8.30)\end{array}$ \\
\hline mfown & $\begin{array}{c}0.424^{* * *} \\
(4.03)\end{array}$ & $\begin{array}{c}0.408^{* *} \\
(2.42)\end{array}$ & $\begin{array}{c}0.539^{* *} \\
(2.33)\end{array}$ & $\begin{array}{c}0.348^{*} \\
(1.65)\end{array}$ & $\begin{array}{l}0.169 \\
(0.80)\end{array}$ & $\begin{array}{c}0.483^{* * * *} \\
(4.32)\end{array}$ \\
\hline MTrade & $\begin{array}{c}17.82^{* * *} \\
(10.74)\end{array}$ & $\begin{array}{c}10.42^{* * *} \\
(2.67)\end{array}$ & $\begin{array}{c}21.52^{* * *} \\
(6.01)\end{array}$ & $\begin{array}{c}21.10^{* * *} \\
(7.49)\end{array}$ & $\begin{array}{c}16.54^{* * * *} \\
(8.00)\end{array}$ & $\begin{array}{c}26.18^{* * * *} \\
(14.57)\end{array}$ \\
\hline Ret_beta & $\begin{array}{c}0.000144^{* * *} \\
(21.84)\end{array}$ & & & & & \\
\hline illiq(avg) & $\begin{array}{c}-566 * * * \\
(-5.71)\end{array}$ & $\begin{array}{c}-301 \\
(-1.48)\end{array}$ & $\begin{array}{c}-842^{* * *} \\
(-4.49)\end{array}$ & $\begin{array}{c}-538 * * * \\
(-3.97)\end{array}$ & $\begin{array}{c}-650 * * * \\
(-3.87)\end{array}$ & $\begin{array}{c}-467 * * * \\
(-5.07)\end{array}$ \\
\hline $\ln ($ size $)$ & $\begin{array}{c}0.101^{* * *} \\
(11.87)\end{array}$ & $\begin{array}{c}0.0504^{* * *} \\
(3.67)\end{array}$ & $\begin{array}{c}0.0923^{* * *} \\
(6.14)\end{array}$ & $\begin{array}{c}0.130^{* * *} \\
(8.93)\end{array}$ & $\begin{array}{c}0.137^{* * * *} \\
(7.48)\end{array}$ & $\begin{array}{c}0.0633^{* * * *} \\
(7.25)\end{array}$ \\
\hline Observations & 60043 & 14960 & 15093 & 15056 & 14934 & 60043 \\
\hline$R^{2}$ & 0.05 & 0.027 & 0.044 & 0.049 & 0.059 & 0.039 \\
\hline
\end{tabular}

Panel B: Controlling for Volatility Comovement

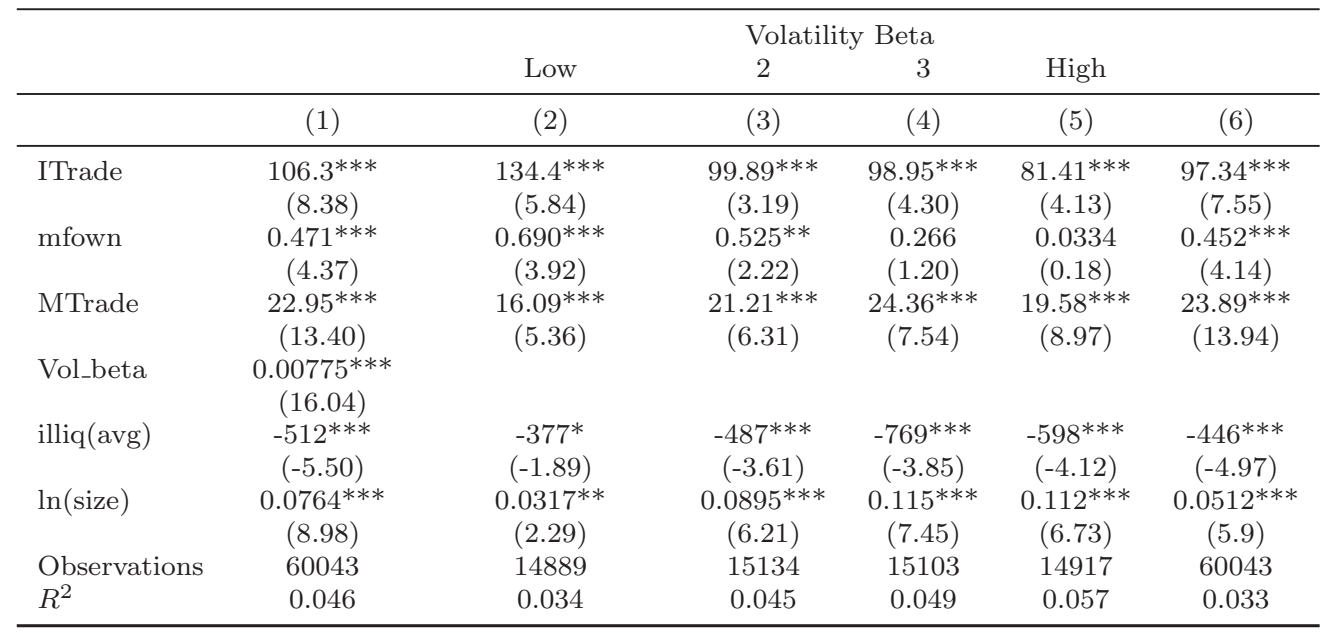




\section{Table 12: Robustness Tests: Liquidity Commonality in a Pair of Stocks}

This table reports Fama-McBeth estimate of monthly cross-sectional regressions forecasting the realized cross-product of changes in stock illiquidity for a sample of stocks. The predictive variables are updated monthly and include different measures of institutional connectedness and a series of controls at time $t$. As measures of connectedness, we use the number of institutions trading in both stocks, $F_{i j, t}$; the total trading volume by all common institutions in dollars of the two stocks scaled by number of shares outstanding of the two stocks, $F_{i j, t}^{T}$; the total cross product of trading volume by all common institutions in dollars of the two stocks scaled by number of shares outstanding of the two stocks, $F_{i j, t}^{C T}$. We measure the negative of the absolute value of the difference in size, $\mathrm{BE} / \mathrm{ME}$ and momentum percentile ranking across the two stocks in the pair ( $D I F F_{-} S I Z E_{i j, t}, D I F F_{-} B E M E_{i j, t}, D I F F_{-} M O M_{i j, t}$ respectively). We also measure the number of similar SIC digits, $N U M_{-} S I C_{i j, t}$ for the two stocks in a pair as well as size percentile of each stock in the pair and an interaction $\left(S I Z E 1_{i j, t}, S I Z E 2_{i j, t}, S I Z E 1 S I Z E 2_{i j, t}\right)$. All independent variables are rank-transformed and normalized to have a unit standard deviation, which we denote with an asterisk superscript. We calculate Newey-West standard errors (four lags) of the Fama-MacBeth estimates that take into account autocorrelation in the cross-sectional slopes.

\begin{tabular}{lccc}
\hline & $(1)$ & $(2)$ & $(3)$ \\
\hline$F^{*}$ & 0.011701 & & \\
& $(7.99)$ & & \\
$F_{i j, t}^{T *}$ & & 0.002818 & \\
$F_{i j, t}^{C T *}$ & & $(2.44)$ & \\
& & & 0.002643 \\
Constant & & & $(2.14)$ \\
& 0.160197 & 0.161106 & 0.161106 \\
& $(7.47)$ & $(7.52)$ & $(7.52)$ \\
DIFF_SIZE* & 0.003348 & 0.003243 & 0.003236 \\
& $(7.15)$ & $(7.04)$ & $(7.07)$ \\
$D I F F_{-} B E M E^{*}$ & 0.00443 & 0.004344 & 0.004339 \\
& $(6.54)$ & $(6.48)$ & $(6.5)$ \\
$D I F F_{-} M O M^{*}$ & 0.008832 & 0.008706 & 0.00869 \\
& $(6.05)$ & $(6.09)$ & $(6.09)$ \\
NUM_SIC & 0.017803 & 0.017939 & 0.017936 \\
& $(16.74)$ & $(16.7)$ & $(16.69)$ \\
SIZE1* & 0.000299 & 0.005268 & 0.005573 \\
& $(0.17)$ & $(2.81)$ & $(2.97)$ \\
SIZE2* & -0.00051 & 0.004488 & 0.004785 \\
& $(-0.3)$ & $(2.55)$ & $(2.7)$ \\
SIZE1SIZE2* & 0.004559 & 0.005145 & 0.005238 \\
& $(12.5)$ & $(12.03)$ & $(12.74)$ \\
\hline
\end{tabular}

